\title{
BIOLOGICAL ANTHROPOLOGY IN THE INDO-PACIFIC REGION: NEW APPROACHES TO AGE-OLD QUESTIONS
}

\author{
Angela L Clark ${ }^{1,2}$, Charlotte L King ${ }^{2}$, Hallie R Buckley ${ }^{2}$, Catherine J Collins ${ }^{2}$, Neha Dhavale ${ }^{2}$, Gail E \\ Elliott $^{2}$, Anna Gosling ${ }^{2}$, Siân E Halcrow ${ }^{2}$, Bradley Ivory ${ }^{3}$, Elizabeth Matisoo-Smith ${ }^{3}$, S Kate McDon- \\ ald $^{3}$, Christina Stantis ${ }^{4}$, Monica Tromp ${ }^{2,5}$, Stacey Ward ${ }^{2}$, Katrina West ${ }^{6}$
}

\begin{abstract}
${ }^{1}$ Sir John Walsh Research Institute, Faculty of Dentistry, University of Otago, New Zealand; 2 Department of Anatomy, University of Otago, New Zealand; ${ }^{3}$ The University of Auckland, New Zealand; ${ }^{4}$ Department of Archaeology, Anthropology and Forensic Science, Bournemouth University, United Kingdom; ${ }^{5}$ Max Planck Institute for the Science of Human History, Department of Archaeology, Jena, Germany; ${ }^{6}$ Trace and Environmental DNA Laboratory, Department of Environment and Agriculture, Curtin University, Perth, Australia.
\end{abstract}

\begin{abstract}
Biological anthropological research, the study of both modern and past humans, is a burgeoning field in the IndoPacific region. It is becoming increasingly apparent that the unique environments of the Indo-Pacific have resulted in an archaeological record that does not necessarily align with those in the northern hemisphere. New, regionallyspecific archaeological models are being developed, and biological anthropological research has an important role to play in establishing past human experience within these models. In the Indo-Pacific, research using ancient and modern human tissues is adding insight into global processes of prehistoric settlement and migrations, subsistence change and human biosocial adaptation. This review synthesises current themes in biological anthropology in this region. It highlights the diverse methods and approaches used by biological anthropologists to address globally-relevant archaeological questions. In recent decades a collaborative approach between archaeologists, biological anthropologists and local communities has become the norm in the region. The many positive outcomes of this multi-disciplinary approach are highlighted here through the use of regionally-specific case studies. This review ultimately aims to stimulate further collaborations between archaeologists, biological anthropologists and the communities in the region, and demonstrate how the evidence from Indo-Pacific research may be relevant to global archaeological models.
\end{abstract}

\section{INTRODUCTION}

The Indo-Pacific region is broadly defined as encompassing eastern Asia and the Pacific (Figure 1), and is perhaps one of the most diverse biogeographical and cultural areas in the world (Lilley, 2017). It encompasses tropical, subtropical and temperate climates; landmasses ranging in scale from continental Southeast Asia to tiny coral atolls; and a vast array of endemic flora, fauna and pathogens.
This wide range of environmental variation provides unprecedented opportunities to assess human adaptation to a myriad of different conditions. The geographic isolation of most of the Pacific Islands and range of physical environments within island groups, has been particularly useful for characterising biological, cultural and linguistic diversity. Humans have a long history in the region, arriving with some of the earliest Out of Africa migrations in Australia and New Guinea (Malaspinas et al., 2016), and migrating through the Pacific to Remote Oceania in what many consider the last major phase of human migration (MatisooSmith and Daugherty, 2012). This extensive time-depth in the region means that biological anthropologists can explore biosocial adaptation using both skeletal remains and modern populations, shedding light on processes that began in the late Pleistocene and continue to influence lives today. This review explores the significance of current biological anthropological research in the Indo-Pacific region for both regional and global understanding of the human story.

In this review, we focus on biological anthropology in island and mainland Southeast Asia, and the Pacific Islands. While other areas of the Indo-Pacific such as South Asia have a long history of archaeological and biological anthropological research (Kennedy, 1980; Lovell and Kennedy, 1989; Mushrif-Tripathy et al., 2016), Southeast Asia and the Pacific have been traditionally under-explored and a review of current research is timely. In addition Southeast Asia and the Pacific are linked by a shared population history, the expansion of people into the Pacific had its origins in mainland and island Southeast Asia possibly occurring as early as 50,000 years ago (Kirch et al., 1989; Summerhayes et al., 2010).

Southeast Asia and the Pacific Islands are especially useful regions for evaluating archaeological paradigms regarding biological and cultural adaptations associated with changes in subsistence strategies. Recent evidence suggests that Southeast Asia may have been one of the locations for the early domestication of chickens (Pitt et al., 2016; Wang et al., 2015), and a route through which the 


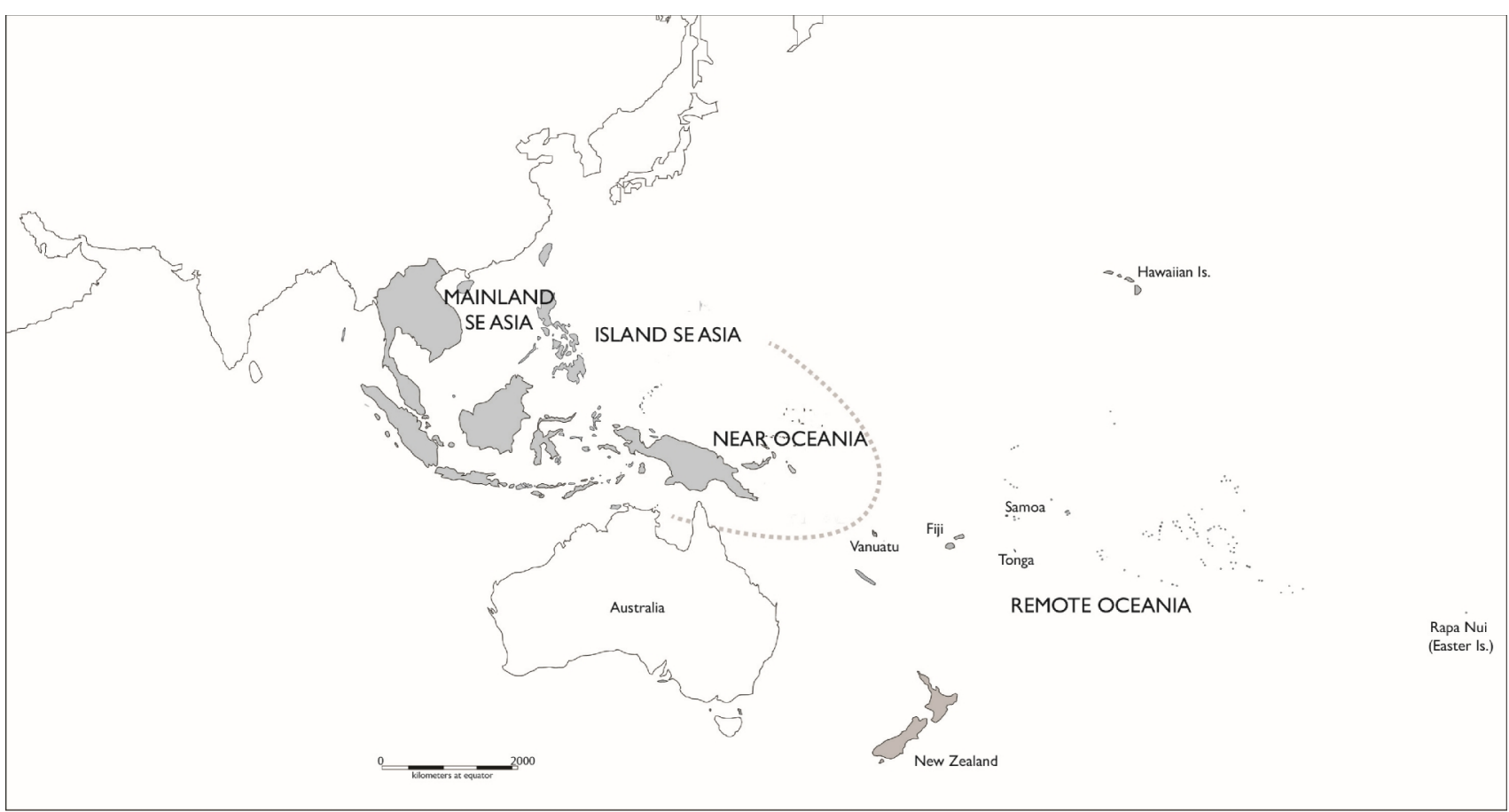

Figure 1: Map showing the Indo-Pacific region, with areas that this article focuses on shaded. Labelled regions and islands are those mentioned in-text.

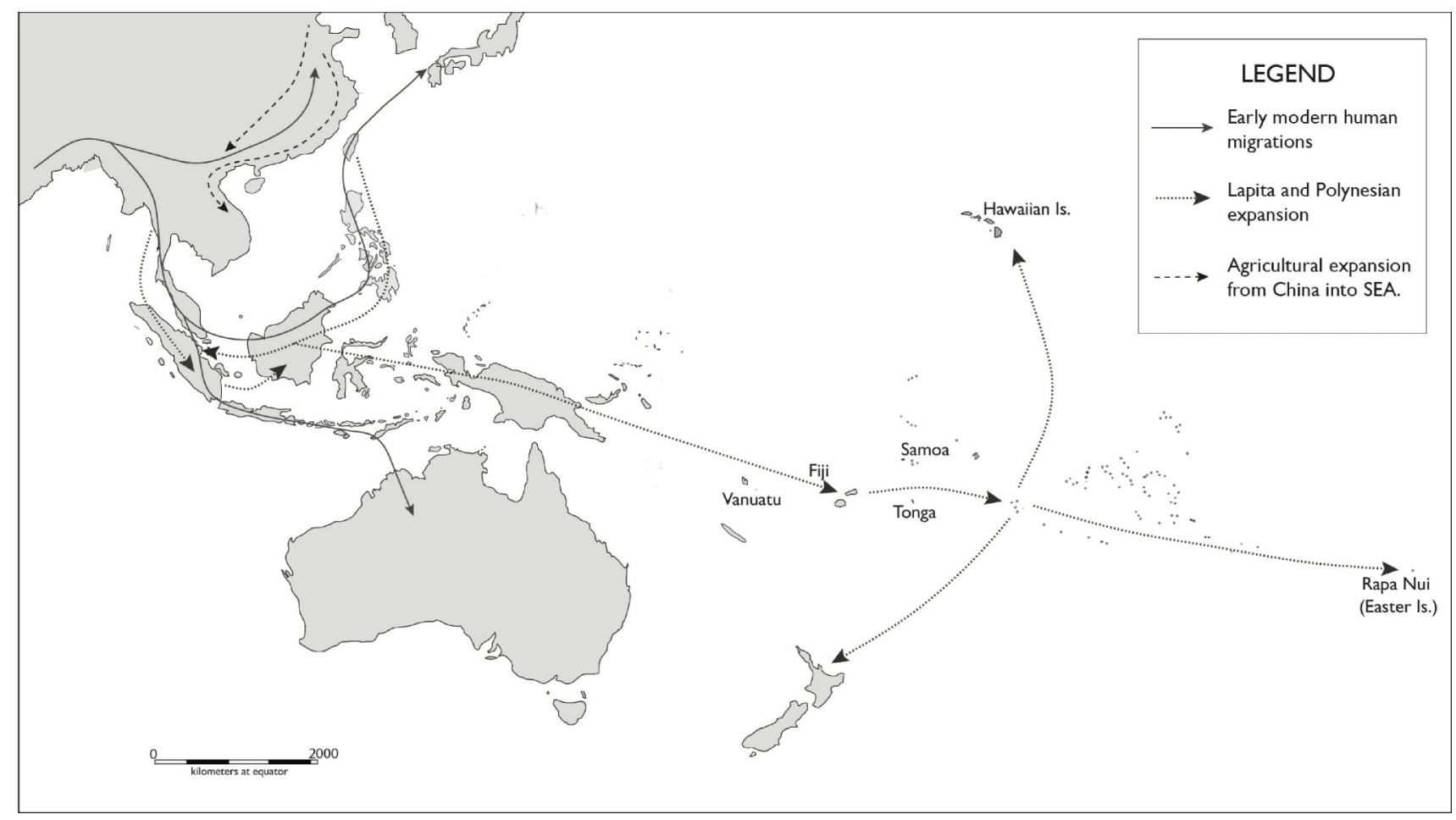

Figure 2: Map of the study area schematically showing major migrations from early modern human movement into the area (50,00040,000BP) to movement of rice agriculturalists into mainland southeast Asia from China ( 4000BP) and Austronesian/Polynesian expansion into the Pacific (3000-750BP). 
domesticated dog was introduced to the Pacific (Greig et al., 2015; Oskarsson et al., 2011; Pang et al., 2009). In addition, both China and New Guinea are centres of independent plant domestication (Denham, 2011; Fuller et al., 2009; Fuller et al., 2014; Gross and Zhao, 2014; Perrier et al., 2011; Yen, 1991). Most archaeological research, and consequently the models drawn from them, is focused on areas in the world reliant on wheat or maize-based subsistence (Cohen and Armelagos, 1984; Roberts and Cox, 2003; Steckel and Rose, 2002). However, Southeast Asian populations generally have a rice-based economy, while the $\mathrm{Pa}-$ cific diet is primarily based on root crops, specifically yam, taro, and sweet potato, in addition to banana and breadfruit. The diversity in subsistence base within the Indo-Pacific region provides biological anthropologists with opportunities to assess human biosocial adaptation to these different subsistence strategies (Halcrow and Tayles, 2011; Kinaston et al., 2015; Kirch, 2010; Spriggs, 1997). This assessment is important as archaeological models based on subsistence change in the Americas, Europe or Near East may not be relevant worldwide, but in the absence of regionally-specific frameworks they are often applied regardless.

Biological anthropological research is significant because evidence obtained from the direct study of human tissues (both archaeological and modern), addresses additional aspects of the human experience to those that can be interpreted through material culture. These investigations include diverse techniques including macroscopic analysis of bone, chemical analysis of tissues, ancient and modern DNA analyses, and investigations of parasites and plant microfossils associated with human tissue as proxies for human health and behaviour. Research involving biological anthropology can provide direct insight into past human mobility, dietary transitions and related adaptations, the implications of climate or environmental change, nutritional deprivation, and the impact of these changes on general population stress and well-being.

There has been a global history of malpractice surrounding the ethical study and curation of human remains and this has included the Asia and Pacific region (see Larsen and Walker (2005) and Watkins (2003) for reviews). Biological anthropology in the Pacific region today involves taking into account the unique sets of beliefs surrounding human remains, death and the spirits of the ancestors (Gilmore et al., 2013; Ruckstuhl et al., 2016). Modern biological anthropologists must both acknowledge this history, and work to build new relationships with local communities. Initial research conducted in the area was colonial and 'race'-based, defined in part by a lack of community consultation regarding the study of populations in both the past and the present (Matisoo-Smith, 2015). A similar history of Western political and economic domination is seen in much of Southeast Asia (Peterson, 1982), with colonial attitudes seriously influencing early interpretations of the region's prehistory (Bayard, 1980; Peterson, 1982). From the mid-1980s onwards, however, biological anthropology began to develop into the research area it is today. In Southeast Asia, recent work is directly opposing early (arguably ethnocentric) interpretations of foreign historical intervention in triggering the rise of complex stratified societies. Instead a long history of local innovation as the primary driver of social change is being revealed (Higham, 2014; O’Reilly, 2014). In the Pacific, biological anthropologists are developing strong research relationships with local communities, addressing the ghosts of past malpractice by working collaboratively to build both research and local identity (Ruckstuhl et al., 2016).

In summary, the Indo-Pacific region has been instrumental in addressing and extending our knowledge of universal archaeological and anthropological research questions; examining where people came from and how they moved around and adapted to their environments. This paper reviews the contribution that biological anthropological research in the Indo-Pacific region has made to the understanding of global archaeological paradigms, dividing this synthesis into three key themes: origins, migration, and biosocial adaptation. These themes are particularly pertinent and interlinked in Southeast Asia and the Pacific. Here researchers are beginning to focus on how population history (i.e. origins and movement of people groups) have impacted both culture and biology (biosocial adaption), ultimately affecting health and disease outcomes in the region today. This review then uses the case study of archaeological work at Wairau Bar (New Zealand) to draw these themes together and illustrate the importance of inter-disciplinary and collaborative work with local communities and researchers.

\section{ORIGINS}

Southeast Asia and the Pacific have highly diverse and deep population histories (see Matisoo-Smith, 2015; Bellwood, 2006), with multiple migrations into and through the area shaping the populations in the region today (Figure 2). Although new genetic data from modern populations is revealing more about human origins in this area, in order to fully address these questions, it is necessary to combine these data with archaeological and bioarchaeological data representing the early inhabitants of the region. Early models of human evolution traditionally focused on Africa and Europe, ignoring much of the evidence from the Indo-Pacific region despite its long human history (Marwick, 2009). Recent palaeontological and genetic research has identified numerous hominin species in the region, as well as evidence of some of the earliest modern human migrations out of Africa. (Malaspinas et al., 2016; Sankararaman et al., 2016). Analysis of the remains from Denisova Cave, for example, has resulted in the discovery of genetic admixture between these previously unidentified hominins and Homo sapiens present in Southeast Asia and the Pacific (Reich et al., 2010). Recently, there have also been suggestions of additional, secondary Neanderthal admixture contributing to the genetic makeup of Asian populations (Vernot et al., 2016; Wall et al., 2013). In addition, the small-bodied hominin Homo floresiensis is also present in the region (Brown et al., 2004), though ancient DNA (aDNA) analyses of this species have to date been unsuccessful (Stringer, 2014). This kind of research highlights 
the important role the Indo-Pacific region plays in understanding the role of admixture in the evolution of our species.

The current focus on palaeontological research in the region means that a new body of information is emerging in the form of combined morphological affinity and genetic work on evolutionary histories. For example, initial morphological studies in the region proposed two distinct migration events to Australia involving a gracile and more robust population (Thorne, 1980). Indeed, the first aDNA analyses of 10 ancient Australians from Lake Mungo and the Willandra Lakes found support for this two phase/ two population settlement scenario (Adcock et al., 2001). Recently, however, researchers have resequenced mitochondrial genomes (mitogenomes) from Mungo 3 and other Willandra Lakes remains (Heupink et al., 2016). Unlike the previous analyses (Adcock et al., 2001) they found continuity between the ancient and modern Australian mitochondrial DNA (mtDNA) sequences, and thus no support for two distinct migration events. Similarly, analyses of 83 whole genomes of modern Aboriginal Australians (Malaspinas et al., 2016) have found not only evidence of a single major migration event to Sahul, but have also identified variations in gene regions associated with thyroid hormone and elevated serum urate levels, which are suggestive of selective adaptations in Australian aboriginals for living in cold, desert environments and for dealing with dehydration. As these examples show, many of the advances in interpretation of population history in the region are being driven by new techniques in aDNA research, in particular the introduction of Next Generation Sequencing (NGS) technologies (Linderholm, 2016; Parks et al., 2015). These techniques give researchers the ability to sequence small pieces of fragmented DNA, which when pieced together can result in coverage of the complete mitogenome, or in some cases even coverage of the nuclear genome of typically degraded ancient samples including samples that would not have produced any reliable sequence data using traditional, Sanger sequencing methods (Koboldt et al., 2013).

Next Generation Sequencing methods also allow for the rapid and relatively inexpensive generation of data for large population level studies using modern DNA. For example, a large number of new complete mitogenomes have recently been generated for modern Pacific populations, which indicate much more mtDNA diversity and population complexity than previously recognised (Duggan et al., 2014). Combined with powerful new methods for statistical analysis, NGS allows for investigation of genome-wide diversity and estimation of levels of genetic admixture (Hellenthal et al., 2014; Lipson et al., 2014). Aboriginal genomes have also recently been sequenced revealing the deep antiquity of the human lineage in Australia, and shedding light on the timing and nature of the Out of Africa migration process (Malaspinas et al., 2016; Rasmussen et al., 2011).

This wealth of new genetic data means researchers can address a range of emerging questions about the evolution and dispersal of the human species (Huerta-Sánchez et al.,
2014; Malaspinas et al., 2016; Mallick et al., 2016; Pagani et al., 2016; Vernot et al., 2016; Xu et al., 2012). Improvements in laboratory techniques and sequencing technologies now allow us to incorporate both data derived from aDNA and sequence data available for contemporary populations when assessing these questions. For example, Pagani et al. (2016) detected admixture between Neanderthal and anatomically modern humans present in the genome sequence of present-day Papuans, suggesting this population derives from a migration earlier than the main migration of modern humans out of Africa. Similarly, admixture with Denisovans has been detected in modern Tibetan genomic data (Huerta-Sanchez et al., 2014) and with both Denisovan and Neanderthal in a contemporary Melanesian dataset (Vernot et al., 2016), highlighting the influence of archaic admixture on human evolution. While Southeast Asia and the Pacific are generally considered to be environments that are not conductive to aDNA preservation, recent analysis (Heupink et al., 2016; Knapp et al., 2012; Skoglund et al., 2016), and continued improvements suggest that it is possible to yield informative DNA sequences from archaeological material in this part of the world.

\section{MIGRATION AND MOBILITY}

Migration is a recurring theme in Indo-Pacific research. Genetic evidence regarding origins indicates that the colonisation of the Pacific through expansion of peoples from Southeast Asia was a multi-faceted process involving numerous populations and complex interactions between them (see Matisoo-Smith (2016) for a review). The movement of the Lapita people, the first colonists of Remote Oceania who are thought to be ancestral to Polynesian populations, began the last chapter of human global colonisation (McNiven et al., 2011; Spriggs, 2011; Figure 2). The geographic separation between the islands of the Indo-Pacific region is useful archaeologically as it allows the teasing apart of processes related to migration from those related to trade and other forms of contact. This is more difficult in mainland Southeast Asia (Fitzpatrick and Anderson, 2008), although it is now recognised that even in the Pacific most islands are unlikely to have ever been completely socioculturally and biologically isolated (Broodbank, 2002; Weisler et al., 2016). Current research in the Pacific is now showing extensive trade links after initial colonisation including retention of contact with the Southeast Asian mainland (Clark, G.R. et al., 2014; D'Arcy, 2006; Kirch, 1988; Lape, 2004). The Indo-Pacific region, therefore, is a dynamic area in which to study human mobility and interaction.

Biological anthropological research into migration has historically focused on cranial morphometrics and dental morphology to identify newcomers in an area, or migrating populations (Hanihara, 1992; Matsumura and Hudson, 2005; Pietrusewsky, 1996a; Pietrusewsky, 1996b; Stefan and Gill, 2016). Using these techniques, bioarchaeologists have demonstrated population affinities between the earliest inhabitants of mainland and island Southeast Asia (Barker et al., 2007; Matsumura et al., 2008b), with mor- 
phometric work culminating in the development of explanatory models such as the Two-Layer hypothesis. This model posits the idea of replacement of Southeast Asian hunter-gatherer populations by agriculturalists (Matsumura et al., 2008a; Matsumura et al., 2011; Matsumura and Oxenham, 2014), and underpins the overarching narrative of population changes associated with agriculture in Southeast Asia.

More recently Southeast Asia and the Pacific have become a focus for genetic research into migrations, associated with both early Lapita settlers and more recent groups. The genetic sequencing of modern Pacific peoples has revealed previously unknown complexity in the histories of island populations (Duggan et al., 2014; Lipson et al., 2014). These modern studies are useful counterparts to aDNA work conducted in the region, especially as aDNA research is limited by poor preservation in the monsoonal and tropical environments of mainland Southeast Asia. The high level of past human mobility and complex migration history of the Indo-Pacific region means that multiple lines of evidence must be used in teasing apart processes of migration from those of trade or diffusion. These kinds of interdisciplinary projects are already well-underway in the region. Isotopic evidence for human movement, for example, is routinely combined with archaeological evidence to examine whether there was a permanent movement of people alongside material culture during trade and exchange processes, and separate this trade from idea diffusion. In the Bismarck Archipelago human and faunal isotopic studies have been used to compare the movement of valued animals and humans (Shaw et al., 2009) and human migration on the south coast of New Guinea (Shaw et al., 2011). Human isotopic values have also been considered in light of similarities and differences in mortuary material culture to differentiate long-distance trade from human migration in Tonga (Stantis et al., 2015), or to suggest groups of socially distinct females in northeast Thailand (Bentley et al., 2009).

The combination of craniometric and genetic evidence has been used to shed light on Lapita expansion and colonisation waves. For example, morphological analysis of five secondary burials of crania from the Lapita site of Teouma in Vanuatu seems to support the idea of a direct Lapita-Asian connection (Valentin et al., 2016). Most recently, researchers have also succeeded in extracting aDNA from the Teouma crania (Skoglund et al., 2016), the results of which may support the initial conclusions of the craniometric study showing Asian genetic affinities. These results, while interesting, derive solely from secondary burials and the burial practices at this site mean that the crania cannot be definitively associated with the postcranial remains. There is therefore much work to be done on fully establishing morphological and genetic affinities in early Pacific assemblages in general, and Teouma in particular. Future work will allow the teasing out of factors such as selective pressures contributing to the development of the Polynesian phenotype and possible Melanesian admixture during Lapita expansion. These latest genetic results, how- ever, do present intriguing data that will generate much discussion regarding the origins, genetic makeup and the homogeneity of Lapita populations through time and space.

In addition to the combination of traditional biological anthropology techniques, the Indo-Pacific region has also been pivotal in the development of the commensal approach to study human migrations. Established in part due to the lack of access to human remains in the Pacific (see introduction), this approach uses aDNA and modern DNA of commensal animals and plants as a model to establish the human origins and settlement of the region (Larson et al., 2007; Matisoo-Smith et al., 2009; Oskarsson et al., 2011; Storey et al., 2013). Results of these studies indicate significant complexity and a range of origins of the different commensal animals in the region; with the origin and movement of pigs, dogs, chickens and rats all suggesting different ancestral sources, paths through island Southeast Asia into the Pacific, and differing timings and numbers of introductions (Matisoo-Smith, 2015). This DNA research has shown not only direct ties between the Pacific Islands, Southeast Asia and South America but also given insight into the timing of horticultural introductions and techniques (Chang et al., 2015; Clarke et al., 2006). The paper mulberry plant has been linked genetically to Taiwan (Chang et al., 2015), and Near Oceanic origins are indicated for taro, sugarcane and banana (Denham, 2011). The complexity of movement around the Pacific is also highlighted by genetic studies of sweet potato that reveal movement out of South America in prehistoric times and later interactions between Central America, the Caribbean, Southeast Asia and the Pacific via early European trade networks (Roullier et al., 2013). Recently, this commensal approach has been expanded to involve isotopic studies, with biological anthropologists using these techniques to trace not only human movement but also the movement of animals, showing continued trade-links between island populations after settlement (Shaw et al., 2009; 2010), or local residence of commensal animals (Kinaston et al., 2013c).

\section{BIOSOCIAL ADAPTATION}

Most biological anthropological research in the Indo-Pacific region adopts a biosocial approach to the study of past populations to shed light on past human experiences. In this approach researchers use demographic factors, in addition to a number of accepted indicators of biological stress, as a measure of health and disease within a population (e.g. Clark, 2018). While "health" can be a problematic term when using a biosocial approach (see Temple and Goodman, 2014), here it is used as a holistic concept representing a general population-based measure of stress, illness and quality of life, based on a variety of skeletal and dental indicators. The biosocial model considers human health as an outcome of both factors of the physical environment and sociocultural context (Figure 3). This general model is not uniquely applied to the Indo-Pacific region (see Larsen, 2015), but is especially useful for the interpretations of health in an area that is both environmentally and culturally diverse. 


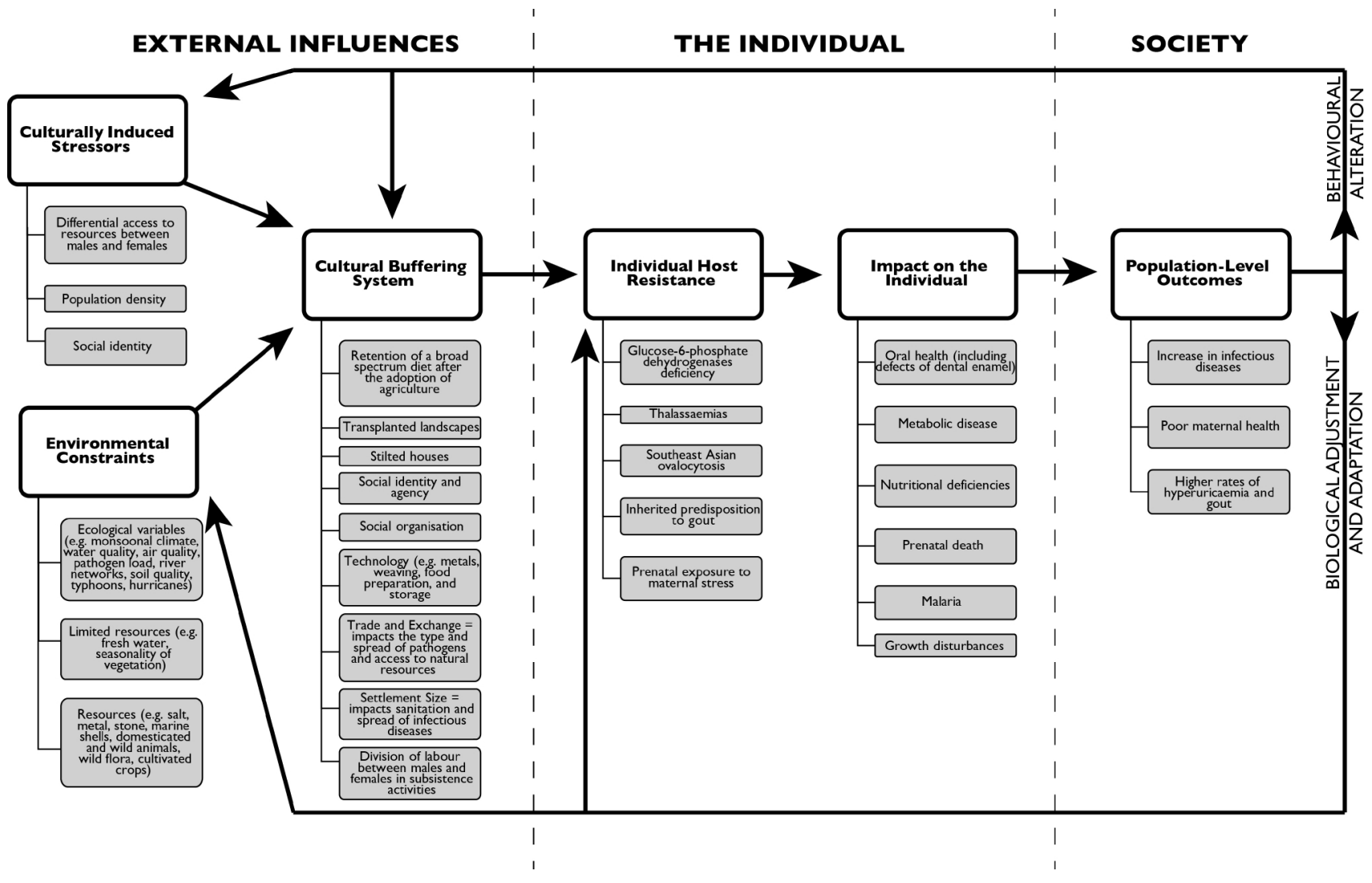

Figure 3. Factors of the physical environment and sociocultural context affecting health outcomes in the Southeast Asian and Pacific contexts.

The many different environments and complex population history of this region provide biological anthropologists with the ability to study the myriad of ways people adapt both biologically and socially to their environments. This discussion focuses on two major themes emerging from research within the Indo-Pacific region. The first of these is the significance of the region for assessing global paradigms relating subsistence change, population dynamics and human health and disease. The second relates to modern-day health in the region and how knowledge of the antiquity of disease and population history may affect current disease presence.

Adaptation to Subsistence Change, Demographic Change and Disease

A major theme in Southeast Asian and Pacific biological anthropology is the impact and significance of subsistence change on human populations. Here, the unique environments and atypical sociopolitical trajectories of the region allow assessment of global paradigms relating to the impact of agriculture. The environmental diversity within the Indo-Pacific region means that there is considerable variation in subsistence practices, social structure, and interaction spheres within the region. In Southeast Asia, the retention of a heavy reliance on broad-spectrum economies even after the adoption of agriculture led to a long, slow transi- tion to full agricultural reliance. This means that the sociopolitical developments and subsequent impacts on health commonly observed elsewhere in the world are not uniformly present (e.g. Domett and Tayles, 2007; Halcrow and Tayles, 2011; Halcrow et al., 2016; Tayles et al., 2000). Similarly, subsistence in the Pacific region is equally complex and does not conform to more generalized global models of agricultural adoption. Here the colonisation of virgin environments gives biological anthropologists the chance to study how humans adapted to these new environments (Buckley et al., 2014). Modification of the environment in the form of transplanted landscapes in the Pacific shows how humans engineered their environment to suit their subsistence needs by translocating species.

The internationally applied subsistence change model posits that the transition to an agricultural-based economy resulted in significant changes to health and sociopolitical organisation (Pinhasi and Stock, 2011). This has implications for diet, weaning, fertility, population dynamics, pathogen-load and human health (Larsen, 1995). In essence, deterioration in the overall quality of life is commonly associated with the transition to a reliance on agricultural crops with a reduction in the nutritional value of food, and an increase in sedentary living arrangements and population size, leading to an increase in infectious disease (Larsen, 1995; Pinhasi and Stock, 2011). However, recent biological anthropological research in mainland Southeast 
Asia and Taiwan has questioned the universal applicability of this central model by showing that human responses to the introduction of agricultural resources were more complex and regionally variable than previously thought (Cheng-Yi et al., 2016; Clark, 2014; Clark, A.L. et al., 2014; Dhavale et al., 2017; Domett, 2001; Domett and Tayles, 2006; Douglas, 1996; Halcrow et al., 2016; Tayles et al., 2009).

Some have argued, based on palaeodemography and female oral health, that there is a change in population dynamics in the Neolithic involving an increase in female fertility (e.g. Willis and Oxenham, 2013). However, this is hard to quantify given the comparative lack of pre-Neolithic samples to compare. Multiple lines of biological anthropological and archaeological evidence are now pinpointing the intensification of agriculture in Southeast Asia as occurring in the Iron Age (c. $500 \mathrm{BC}$ to $500 \mathrm{AD}$ ), at which point a deterioration in health is observable in several regions (Halcrow et al., 2016; King et al., 2017). This change in population stress and disease is echoed in major cultural and environmental changes observed in the archaeological record during this transitional period (Boyd and Chang, 2010; Higham, 2016; Wohlfarth et al., 2016; Yamoah et al., 2017). Archaeological and biological anthropological analyses are now being combined to provide insight on health in relation to these social changes (Ward et al., In Press). Research from prehistoric mainland Southeast Asia highlights how the speed of agricultural resource uptake results in differential biosocial responses, and illustrates how important the consideration of environmental context is when applying generalised global models.

Historically, a paucity of founding population cemetery samples in the Pacific has limited the opportunities to assess the interactions between human subsistence choices and the island environments. However, recent excavations and analysis of human skeletal samples from Lapita contexts and post-Lapita cemetery sites are beginning to build a picture of early settler health, diet and adaptation (Horrocks et al., 2014; Kinaston et al., 2014a, 2014b; Kinaston et al., 2016; Valentin et al., 2010; Valentin et al., 2014). The Lapita colonists travelled with an agricultural package including tuberous crops, pigs, dogs, and chickens to new island environments where they also took advantage of diverse indigenous plants and animals. Multiple lines of biological anthropological research support the idea of crop translocation, including plant microfossils (starch grains and phytoliths) found in dental calculus (Dudgeon et al., 2016; Horrocks et al., 2014; Tromp and Dudgeon, 2015), and isotopic evidence for terrestrial crop use in some of the earliest Pacific settlers (Kinaston et al., 2013c).

The practice of translocating plant and animal species and relying on them for stable food sources may have had significant health implications for the early colonists. The introduced species are likely to have been vulnerable to the new conditions of each island environment, resulting in resource instability and consequent nutritional deficiencies (Buckley et al., 2014). Biological anthropological evidence is also revealing the use of endemic resources in mitigating the effects of poor crop yield. Microfossil analysis indicates the importance of both wild and cultivated food sources on islands such as Efate, Vanuatu, generally showing a much broader plant diet than has been previously assumed in major migration models (Tromp, 2016). Furthermore, isotopic analysis indicates that on some islands where soils were poor, diverse human coping strategies were employed, including crop fertilisation (Commendador et al., 2013), and lessening reliance on agricultural crops in favour of using marine resources (Stantis et al., 2016b). In the Pacific, periods of social and environmental change have also provided biological anthropologists with the opportunity to study social inequality and its effect on food distribution and subsistence patterns (Fenner et al., 2015; Kinaston et al., 2013a, 2013b; Stantis et al., 2015; 2016a; Valentin et al., 2006). These studies have generally shown greater consumption of protein-rich foods in higher social classes and a ubiquitous lower consumption of protein in females compared to males.

Alongside investigations of the demographic effects of subsistence change, research is also being conducted to establish the impact of agriculture on human health. Commonly used indicators of health include stature and body size, oral health, developmental defects of dental enamel, metabolic disease, and the presence of infectious disease (Larsen, 2015). Within mainland Southeast Asia, there is no indication of a pattern of health change with the transition to agriculture. There is, however, some evidence for the increase in specific infectious disease in the Iron Age, including possible tuberculosis (or brucellosis) and leprosy (Oxenham et al., 2005; Tayles and Buckley, 2004). Metabolic disease, probable scurvy, has also been identified in the Iron Age Laos and historic period Cambodia (Halcrow and Boonlop, 2014; Halcrow et al., 2014). Recent work examines the individual and population level responses to infectious agents by modelling the effects of likely pathogens endemic to the region (Clark et al., 2015; King et al., 2017). By considering context-specific factors, biological anthropologists can characterise how health and disease may be impacted, providing a more detailed understanding of regional variation.

Biological anthropological research in the Pacific also focuses on the themes of health and population dynamics. However, the island environments of this region raise different questions than those addressed in Southeast Asia. In particular, research in this region focuses on how colonisation processes may have affected human health and population growth (e.g. Buckley 2016; Pietrusewsky et al., 2014). In moving to new islands and partially relying on a translocated horticultural package, early settlers will have experienced new pathogens, potential problems relating to lower genetic diversity of small founding populations, and environmental instability (Buckley et al., 2014). Small founding populations in the Pacific allow biological anthropologists to answer questions regarding how colonisation occurred and populations grew (Whyte et al., 2005). Similarly, to parts of Asia, the tropical environment of many of the Pacific Islands has implications for pathogen 
distribution, and colonising and later populations were potentially burdened with a high levels of physiological and psychological stress (Buckley et al., 2008; Pietrusewsky et al., 1997; 2014). While we cannot confirm that we are examining psychosocial stress archaeologically, there are many aspects of health that can be examined using biological anthropological evidence. Large cemetery samples in the Pacific are rare, but those that do exist are allowing biological anthropologists to model and understand colonisation processes and health changes occurring in this area.

Research on the largest Lapita cemetery (Teouma in Vanuatu), for instance, has revealed a significant burden of prenatal death, likely reflecting poor maternal health in this population (Buckley et al., 2014; Kinaston et al., 2009). This may be related to differential access to resources between males and females during the initial colonisation phase (Kinaston et al., 2014b). Comparison to later Lapita sites is also beginning to allow the assessment of changes to health and diet as people become established in Vanuatu (Kinaston et al., 2014b; Valentin et al., 2014). There is also palaeopathological evidence for dietary insufficiencies in both the children and adults of founding Lapita populations, indicating that resource instability negatively affected health, resulting in scurvy or vitamin $\mathrm{C}$ deficiencies (Buckley et al., 2014).

\section{Modern-day Health and Links to Evidence of Disease in the Past}

Many countries in the Indo-Pacific region are at the forefront of global economic change. Yet more than a billion people in this region remain vulnerable to disease (World Health Organisation, 2014). Modern-day communicable diseases found in the Indo-Pacific perpetuate the cycle of poverty and poor health, and much of this disease burden today can be attributed to neglected tropical diseases (NTDs). NTDs are a group of diseases caused by parasites, bacteria, viruses, and other organisms. The most common NTDs in the Indo-Pacific region include: soil-transmitted helminthiases (intestinal worms), foodborne trematodiases (liver and lung flukes), leprosy, lymphatic filariasis (elephantiasis), schistosomiasis (snail fever), trachoma and yaws (World Health Organisation, 2014). Many of these diseases are associated with unsafe water and sanitation, and unique cultural practices of food preparation (i.e. eating raw fish in Thailand (Sithithaworn and Haswell-Elkins, 2003)) in a tropical environment. The disease burden of these pathogens in the present is likely to have been just as significant in the past (King et al. 2017), and although many of these diseases do not leave diagnostic traces on the skeleton, it may be plausible to infer their presence. Research into the antiquity of disease and population history in this region has the potential to inform clinical outcomes and models of modern-day epidemiology.

Differential diagnosis of skeletal evidence of diseases in archaeological samples is relatively commonplace in both the Pacific and Southeast Asia. This type of analysis is useful as it allows not only evaluation of archaeological hypotheses, but also has implications for human adaptation to disease and modern population health. In the Pacific, for instance, the diagnosis of disease in the past has allowed assessment of migration-based hypotheses (Buckley and Tayles, 2003). It was assumed that treponemal diseases had a long history in the Pacific, entering with the first settlers ultimately originating from Southeast Asia (Trembly, 1996). However, recent palaeopathological findings from pre-1500 $A D$ skeletons from the region cast doubt on this assumption, suggesting that the transmission of treponemal diseases is much more recent and complex, perhaps reflecting later human interactions (Buckley and Oxenham, 2016). It has also been possible to use modern human genetic adaptations (e.g. Clark and Kelly, 1993) alongside the genetics of the pathogens themselves (Mokrousov et al., 2016) and palaeopathological evidence for disease (Gosling et al., 2014a) to trace human colonisation pathways.

Inherently, when organisms encounter new infectious pathogens, biological and/or social adaptations become fundamental to survival (Karlsson et al., 2014). The antiquity of certain diseases in the Indo-Pacific region, therefore, has resulted in biosocial adaptation that has had longterm impacts on culture, biology and disease experience. For example, malaria is currently recognised as one of the greatest evolutionary adaptive forces in the recent history of the human genome (Kwiatkowski, 2005). Malaria has a long, but undated, antiquity in the Indo-Pacific region. It is endemic to mainland and island Southeast Asia, coastal New Guinea, the Solomon Islands and Vanuatu. In these regions, malaria is likely to have affected both population growth and mortality rates in the past (Groube, 1993; Kirch, 2000; Pietrusewsky and Douglas, 2002; Tayles, 1999). Modern studies reveal that the long presence of malaria in the region has resulted in a wide-variety of genetic adaptations to malarial exposure, including glucose-6phosphate dehydrogenase deficiency, the thalassaemias and Southeast Asian ovalocytosis (Flint et al., 1986; Fowkes and Day, 2008; Hill et al., 1985; Philippon et al., 1995; Ubalee et al., 2005). The high frequencies of some of these mutations found in populations of Remote Oceania, where malaria has never been endemic, provide additional support for models of population history. It is likely that the ancestral population of Remote Oceania were exposed to endemic malaria as they moved through the $\mathrm{Pa}$ cific as they carry high levels of alpha thalassaemia mutations, which are advantageous for surviving in malarial environments (Flint et al., 1986; Hill et al., 1985). It has also recently been suggested that adaptation to malaria might also be an explanation for the high rates of hyperuricaemia and gout in Pacific populations (Gosling et al. 2014b). In addition to biological adaptation to malaria, there is also strong archaeological evidence for cultural responses to the disease, including the use of stilted houses in Lapita settlements to reduce the proximity to vector habitats (Kirch, 2000).

Metabolic disease research in the Pacific region is also shedding new light on the antiquity of disease and population responses. Many contemporary Pacific populations suffer a high prevalence of gout and other metabolic diseases (Buckley, 2011; Gosling et al., 2014a; Gosling et al., 
2014b). The high prevalence of gout was previously assumed to be primarily a result of transitioning to westernised diets and sedentary lifestyles. However, the integration of genetic and archaeological data with modern clinical research in the region is challenging this assumption. Historical research (Gosling et al., 2014b) combined with palaeopathological identification of diagnostic lesions (Buckley, 2011; Buckley, 2007; Snow, 1974) has established a deep time-depth for these conditions. It has therefore been proposed that the high rates of disease in modern populations may be a result of ancestry and an inherited genetic predisposition to disease (Hollis-Moffatt et al., 2009; Phipps-Green et al., 2010). These findings have been valuable in initiating discussions with communities about this disease burden and promoting education through community initiatives such as the Māori Gout Action Group (Winnard et al., 2008).

\section{MOVING FORWARD WITH COMMUNITY-DRIVEN RESEARCH: WAIRAU BAR AS A CASE STUDY}

The recent re-examination of kōiwi tangata (Māori ancestral remains) from Wairau Bar (New Zealand) prior to their return and reburial by their descendant community provides a useful example of how aspects of biological anthropology reviewed in this paper (origins, migration and biosocial adaptation) are being investigated in Indo-Pacific sites. Work at Wairau Bar is also an excellent illustration of how positive engagement between local groups and researchers can aid in interpretation of the past (Ruckstuhl et al., 2016). We expand upon this case study to explore some of the ways in which Indo-Pacific biological anthropology is moving forward, particularly in the field of communitydriven research.

Wairau Bar is located on the northern coast of the South Island of New Zealand (Figure 4) and is one of the only founder-phase sites in New Zealand, inhabited during the earliest period of colonisation (Higham et al., 1999). The site was originally excavated in the 1940 s to 1960 s (Brooks et al., 2011; Duff, 1977) with limited consultation with descendent communities. Controversially, the 42 people represented by human remains recovered from Wairau Bar were held in a regional museum. However, in 2009 they were repatriated to the Māori community (iwi) who currently have guardianship over the area (Buckley et al., 2010). This process of repatriation involved re-excavation of part of the site in preparation for reinterment. During this time extensive consultation with local $i w i$ was undertaken and a Memorandum of Understanding drawn-up to allow renewed biological anthropological study of the human remains from the site (Ruckstuhl et al., 2016).

The site's potential to answer important questions about early human colonisation of New Zealand, and the ways humans adapted to the environments they encountered there was recognised early on in the research process. As early coloniser sites in New Zealand are rare, there was a concerted effort for collaboration between archaeologists, biological anthropologists and the community at Wairau Bar, primarily because all parties recognise its importance. This collaborative approach involved multiple lines of biological research including palaeopathological (Buckley et al., 2010), aDNA (Knapp et al., 2012), isotopic analyses (Kinaston et al., 2013c), and facial approximation (Hayes et al., 2012). The biological evidence was combined with analyses of material culture (Walter et al., 2006) and archaeozoological research relating to commensal and native species (Greig et al., 2015; Jacomb et al., 2014; Wilmshurst et al., 2008). The vast amount of data emerging from Wairau Bar means that research is ongoing, and there is still much to be discovered.

The reanalysis of the kōiwi tangata prior to reburial extended and, in some cases, clarified earlier analyses of the burials (Houghton 1975) including identification of gout and likely tuberculosis in the population, different demographic structure between the burial groups, and differential health patterns between males and females (Buckley et al, 2010). Isotopic studies have also indicated different patterns between the burial groups, with group 1, which contained not only the best-preserved remains, but also a large number of burial goods, having similar diets and similar childhood origins, which did not appear to be local. The isotopic results for burial groups 2 and 3 were much more variable in terms of diets and likely childhood environments (Kinaston et al., 2013c). The aDNA evidence from the Wairau Bar kōiwi tangata also provided some surprising results. Knapp et al. (2012) were able to obtain complete or near complete mitogenomes from four of the burials, and all four had different haplotypes, or maternal lineages. As the research continues several additional haplotypes have been found which together have implications regarding the number of founding females and ultimately for reconstructing the demographic history of New Zealand (Whyte et al., 2005).

The work being undertaken at Wairau Bar highlights the unique position of Pacific biological anthropology to shed light on processes of colonisation and human adaptation. The collaborative approach, in this instance, reveals a picture of a genetically diverse and mobile founding population. Research undertaken has enabled the exploration of the health and lifestyle in the earliest New Zealanders. Collaboration with descendant communities, including DNA sampling of $i w i$ members means that cultural and genetic links between ancestral and modern population can be more fully explored. For the first time, the faces and lifestyles of the ancestors are being revealed to their descendants. As the usefulness of biological anthropology in constructing and supporting indigenous identity is highlighted, further community-lead research is being encouraged, and new research projects developed.

The work at Wairau Bar highlights the more general theme of community-based research emerging particularly in the Pacific region. Biological evidence and local involvement are no longer considered add-ons to the archaeology. Instead, community participation and biological anthropology are integral research components, which are beginning to drive research design in the Indo-Pacific region. The unethical manner in which human remains were collected throughout much of the Pacific region (see introduction) in the 19th and 20th century cannot be glossed over 


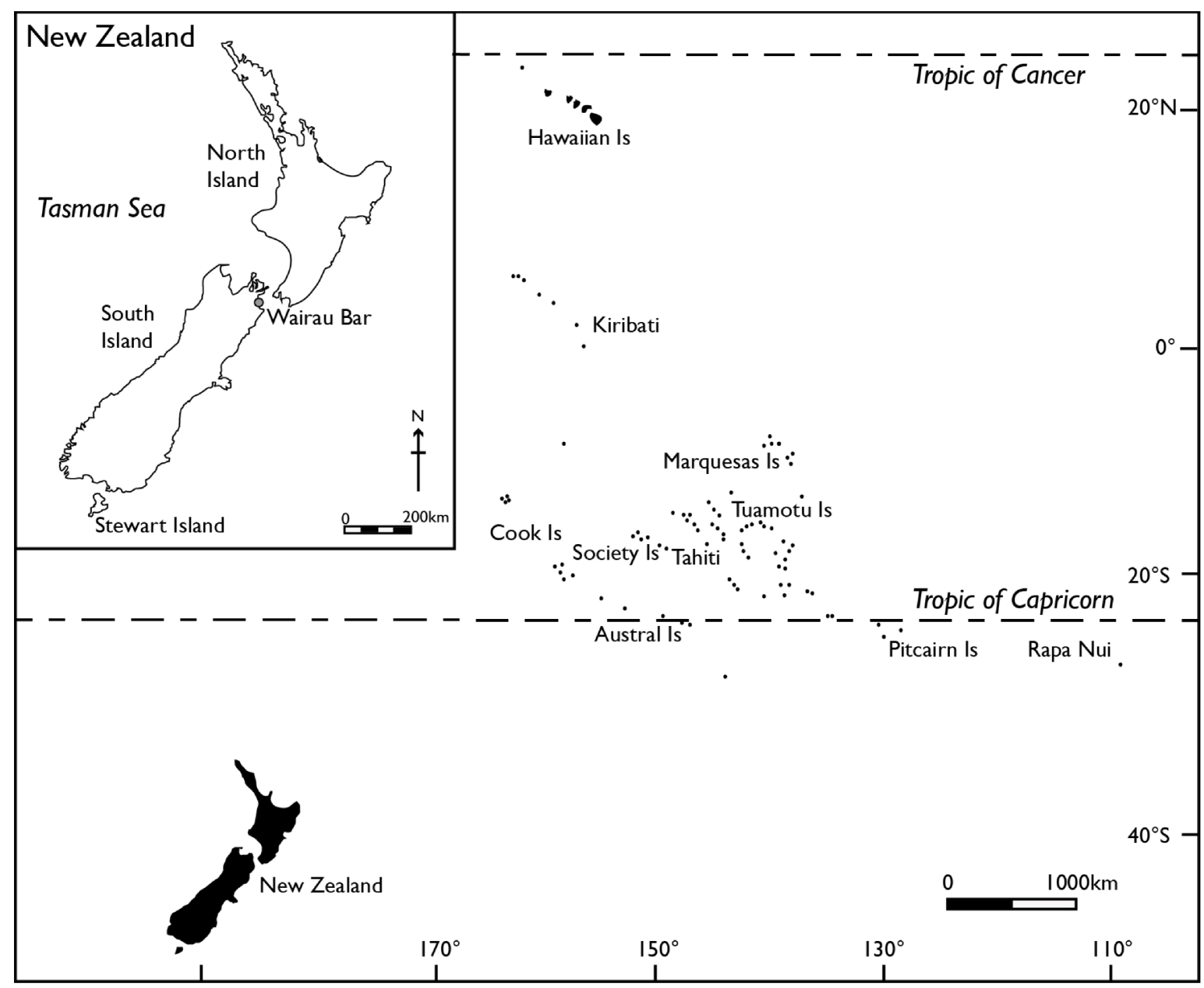

Figure 4: Location of Wairau Bar in the Pacific and New Zealand (inset). Figure reproduced with authors' permissions from Kinaston et al. $(2013 a)$.

or ignored, but it does appear we are entering a new chapter in research collaboration. Slowly trust is being regained and new relationships established (Bedford et al., 2011; Ruckstuhl et al., 2016) and we advocate for such approaches.

\section{CONCLUSION}

Biological anthropological research in the Indo-Pacific region emphasises the diversity of life experiences and social changes during prehistory. Here, multiple lines of evidence are indicating retention of broad-spectrum subsistence choices in productive and diverse environments. Research in this region is allowing characterisation of subsistence diversity and demonstrating that models built using archaeological and biological anthropological evidence from Europe, the Near East and North America are not globally applicable.

Biological anthropological research has added new dimensions to the understanding of the human story in the region. The biosocial approach provides essential context for understanding the cultural and biological complexity present not only in the past, but also in the modern world. For example, the study of biological and cultural adaptation to malaria in ancient and modern Pacific populations is shedding light on migration pathways and ancestral links in this region, as well as informing modern-day health research into the prevalence of disease.

This synthesis highlights the merits of biological anthropological research in the Indo-Pacific region. However, in order to make detailed and accurate interpretations, it is necessary to combine these data with other lines of evidence. There is growing recognition that investigation of the past needs to be multidisciplinary, incorporating evidence from archaeology with human remains and the perspectives of the descendent communities. The research undertaken at Wairau Bar epitomises this collaborative approach in combining archaeology, biological anthropology and community involvement. Research arising from 
Wairau Bar is answering important academic questions regarding settlement processes and adaptation to the New Zealand environment. But, perhaps more significantly, the collaborative approach also has wider impacts, encouraging outreach and continued engagement with local and descendent communities.

\section{ACKNOWLEDGEMENTS}

This review of biological anthropology in the Indo-Pacific is only possible because of the myriad of researchers who are working tirelessly in the region and the communities themselves who are willing to involve archaeologists in their histories. In particular, the authors would like to thank Nancy Tayles, whose work has inspired so many of us, and whose academic support has been invaluable in building biological anthropology in the Indo-Pacific region. We would also like to thank the four anonymous reviewers for their comments, which have added substantially to the manuscript.

\section{REFERENCES}

Adcock, G. J., Dennis, E. S., Easteal, S., Huttley, G. A., Jermiin, L. S., Peacock, W. J. and Thorne, A. 2001. Mitochondrial DNA sequences in ancient Australians: implications for modern human origins. Proceedings of the National Academy of Sciences 98(2): 537-542.

Barker, G., Barton, H., Bird, M., Daly, P., Datan, I., Dykes, A., Farr, L., Gilbertson, D., Harrisson, B. and Hunt, C. 2007. The 'human revolution' in lowland tropical Southeast Asia: the antiquity and behavior of anatomically modern humans at Niah Cave (Sarawak, Borneo). Journal of Human Evolution 52(3): 243-261.

Bayard, D. 1980. The roots of Indochinese civilisation: recent developments in the prehistory of Southeast Asia. Pacific Affairs 53(1): 89-114.

Bedford, S., Regenvanu, R., Spriggs, M., Buckley, H. and Valentin, F. 2011. Vanuatu. In N. Marquez-Grant and L. Fibiger (eds.) The Routledge Handbook of Archaeological Human Remains and Legislation. pp. 657-672. New York: Routledge.

Bellwood, P. 2006. Asian farming diasporas? Agriculture, languages, and genes in China and Southeast Asia. In M. T. Stark (ed.) Archaeology of Asia. pp. 96-118. Malden, MA: Blackwell.

Bentley, G. C. 1986. Indigenous states of Southeast Asia. Annual Review of Anthropology 15(1): 275-305.

Bentley, R. A., Cox, K., Tayles, N., Higham, C. F. W., Macpherson, C., Nowell, G., Cooper, M. and Hayes, T. E. 2009. Community diversity at Ban Lum Khao, Thailand: isotopic evidence from the skeletons. Asian Perspectives 48(1): 79-97.

Boyd, W. E. and Chang, N. 2010. Integrating social and environmental change in prehistory: a discussion of the role of landscape as a heuristic in defining prehistoric possibilities in NE Thailand. In S. Haberle, J. Stevenson and M. Prebble (eds.) Altered Ecologies - Fire, Climate and Human Influence on Terrestrial Landscapes. Terra Australis 21. pp. 273-297. Canberra, ACT: ANU E Press.

Broodbank, C. 2002. An Island Archaeology of the Early Cyclades, Cambridge: Cambridge University Press.
Brooks, E., Walter, R. and Jacomb, C. 2011. History of excavations at Wairau Bar. Records of the Canterbury Museum 25: 13-58.

Brown, P., Sutikna, T., Morwood, M. J., Soejono, R. P., Saptomo, E. W. and Due, R. A. 2004. A new small-bodied hominin from the Late Pleistocene of Flores, Indonesia. Nature 431(7012): 1055-1061.

Buckley, H. R. 2007. Possible gouty arthritis in Lapita-associated skeletons from Teouma, Efate Island, central Vanuatu. Current Anthropology 48(5): 741-749.

Buckley, H. R. 2011. Epidemiology of gout: perspectives from the past. Current Rheumatology Reviews 7(2): 106-113.

Buckley, H. R. 2016. Health and disease in the prehistoric Pacific Islands. Oxford, UK: British Archaeological Reports, 233p.

Buckley, H. R. and Oxenham, M. 2016. Bioarchaeology in the Pacific Islands: a temporal and geographical examination of nutritional and infectious disease. In M. Oxenham and H. R. Buckley (eds.) The Routledge Handbook of Bioarchaeology in Southeast Asia and the Pacific Islands. pp. 363-388. New York: Routledge.

Buckley, H. R. and Tayles, N. 2003. Skeletal pathology in a prehistoric Pacific Island sample: issues in lesion recording, quantification, and interpretation. American Journal of Physical Anthropology 122(4): 303-324.

Buckley, H. R., Kinaston, R., Halcrow, S. E., Foster, A., Spriggs, M. and Bedford, S. 2014. Scurvy in a tropical paradise? Evaluating the possibility of infant and adult vitamin C deficiency in the Lapita skeletal sample of Teouma, Vanuatu, Pacific islands. International Journal of Paleopathology 5: 72-8.

Buckley, H. R., Tayles, N., Halcrow, S. E., Robb, K. and Fyfe, R. 2010. The people of Wairau Bar: a re-examination. Journal of Pacific Archaeology 1(1): 1-20.

Buckley, H. R, Tayles, N., Spriggs, M. J. T., Bedford, S. 2008. A Preliminary Report on Health and Disease in Early Lapita Skeletons, Vanuatu: Possible Biological Costs of Island Colonization. The Journal of Island and Coastal Archaeology. 3: 87-114.

Chang, C.-S., Liu, H.-L., Moncada, X., Seelenfreund, A., Seelenfreund, D. and Chung, K.-F. 2015. A holistic picture of Austronesian migrations revealed by phylogeography of Pacific paper mulberry. Proceedings of the National Academy of Sciences 112(44): 13537-13542.

Cheng-Yi, L., Maa-Ling, C., Ditchfield, P., Lin, L.-H., Wang, P.L., Pollard, A., Lin, H.-M., Lo, C.-H. and Tsai, H.-K. 2016. Diet and subsistence mode of Neolithic Yuan-Shan people in Taiwan: perspective from carbon and nitrogen isotope analyses of bone collagen. Archaeological Research in Asia 7: 18-27.

Clark, A. L. 2014. Health and sexual dimorphism at Ban Non Wat: the effects of the intensification of agriculture in prehistoric Southeast Asia. Bulletins et Mémoires De La Société D'Anthropologie de Paris 26(3-4): 196-204.

Clark, A. L. 2018. Physiological Stress. In W. Trevathan (ed.) The International Encyclopedia of Biological Anthropology. Hoboken, NJ: John Wiley and Sons, Inc. (In Press)

Clark, A. L., Tayles, N. and Halcrow, S. 2014. Aspects of health in prehistoric mainland Southeast Asia: indicators of stress in response to the intensification of rice agriculture. American Journal of Physical Anthropology 153(3): 484495 . 
Clark, A. L., Tayles, N., Halcrow, S. and Buckley, H. 2015. Neglected tropical diseases in prehistory: skeletal evidence of differential diagnosis from Northeast Thailand. Otago Global Health Institute Annual Conference. Dunedin. [Abstract]

Clark G. R., Reepmeyer C., Melekiola N., Woodhead J., Dickinson W.R. and Martinsson-Wallin H. 2014. Stone tools from the ancient Tongan state reveal prehistoric interaction centers in the Central Pacific. Proceedings of the National Academy of Sciences 111(29):10491-10496.

Clark, J. T. and Kelly, K. M. 1993. Human genetics, paleoenvironments, and malaria: relationships and implications for the settlement of Oceania. American Anthropologist 95(3): 612-630.

Clarke, A. C., Burtenshaw, M. K., McLenachan, P. A., Erickson, D. L. and Penny, D. 2006. Reconstructing the origins and dispersal of the Polynesian bottle gourd (Lagenaria siceraria). Molecular Biology and Evolution 23(5): 893900.

Cohen, M. N. and Armelagos, G. J (eds.) 1984. Paleopathology at the Origins of Agriculture, New York: Academic Press.

Commendador, A. S., Dudgeon, J. V., Finney, B. P., Fuller, B. T. and Esh, K. S. 2013. A stable isotope $\left(\delta^{13} \mathrm{C}\right.$ and $\left.\delta^{15} \mathrm{~N}\right)$ perspective on human diet on Rapa Nui (Easter Island) ca. AD 1400-1900. American Journal of Physical Anthropology 152(2): 173-185.

D'Arcy, P. 2006. The People of the Sea: Environment, Identity, and History in Oceania Honolulu: University of Hawaii Press.

Denham, T. 2011. Early agriculture and plant domestication in New Guinea and Island Southeast Asia. Current Anthropology 52(S4): S379-S395.

Dhavale, N., Halcrow, S.E. Buckley, H.R., Tayles, N., Domett, K.M., and Grey, A.R. 2017. Linear and appositional growth in infants and children from the prehistoric settlement of Ban Non Wat, Northeast Thailand: Evaluating biological responses to agricultural intensification in Southeast Asia. Journal of Archaeological Science: Reports 11: 435-446.

Domett, K. 2001. Health in Late Prehistoric Thailand Oxford: Archaeopress.

Domett, K. and Tayles, N. 2006. Adult fracture patterns in prehistoric Thailand: a biocultural interpretation. International Journal of Osteoarchaeology 16(3): 185-199.

Domett, K. and Tayles, N. 2007. Population health from the Bronze to the Iron Age in the Mun River valley, northeastern Thailand. In M.N Cohen and G. CraneKramer (eds.) Ancient Health: Skeletal Indicators of Agricultural and Economic Intensification. pp. 286-299. Gainsville, FL : University Press of Florida.

Douglas, M. T. 1996. Paleopathology in Human Skeletal Remains from the Pre-Metal, Bronze and Iron Ages, Northeastern Thailand [unpublished $\mathrm{PhD}$ thesis]. University of Hawai'i.

Dudgeon, J., Commendador, A. and Tromp, M. 2016. Archaeogenetics and paleodemographic estimation of founding populations, and features of residential geography on Rapa Nui (Easter Island). In V. Stefan and G. W. Gill (eds.) Skeletal Biology of the Ancient Rapanui (Easter Islanders). pp. 202-221.Cambridge: Cambridge University Press.
Duff, R. 1977. The Moa-Hunter Period of Maori culture. Wellington: Government Printer.

Duggan, A. T., Evans, B., Friedlaender, F. R., Friedlaender, J. S., Koki, G., Merriwether, D. A., Kayser, M. and Stoneking, M. 2014. Maternal history of Oceania from complete mtDNA genomes: contrasting ancient diversity with recent homogenization due to the Austronesian expansion. The American Journal of Human Genetics 94(5): 721-733.

Fenner, J. N., Clark, G., Cressey, A., Valentin, F., Olesen, S. H. and Armstrong, R. 2015. Isotopic uniformity and segregation in Tongan mounds. Journal of Archaeological Science: Reports 2: 644-653.

Fitzpatrick, S. M. and Anderson, A. 2008. Islands of isolation: archaeology and the power of aquatic perimeters. The Journal of Island and Coastal Archaeology 3(1): 4-16.

Flint, J., Hill, A., Bowden, D., Oppenheimer, S., Sill, P., Serjeantson, S., Bana-Koiri, J., Bhatia, K., Alpers, M. and Boyce, A. 1986. High frequencies of alpha-thalassaemia are the result of natural selection by malaria. Nature 321 : 744-750.

Fowkes, F. J. and Day, K. P. 2008. Alpha thalassaemia and malaria in melanesia: epidemiological perspectives. Papua New Guinea Medical Journal 51(3/4): 131-137.

Fuller, D. Q., Denham, T., Arroyo-Kalin, M., Lucas, L., Stevens, C. J., Qin, L., Allaby, R. G. and Purugganan, M. D. 2014. Convergent evolution and parallelism in plant domestication revealed by an expanding archaeological record. Proceedings of the National Academy of Sciences 111(17): 6147-6152.

Fuller, D. Q., Qin, L., Zheng, Y., Zhao, Z., Chen, X., Hosoya, L. A. and Sun, G.-P. 2009. The domestication process and domestication rate in rice: spikelet bases from the Lower Yangtze. Science 323(5921): 1607-1610.

Gilmore, H., Schafer, C. and Halcrow, S. E. 2013. Tapu and the invention of the "death taboo": an analysis of the transformation of Polynesian cultural concept. Journal of Social Archaeology 13(3): 331-349.

Gosling, A. L., Matisoo-Smith, E. and Merriman, T. R. 2014a. Hyperuricaemia in the Pacific: why the elevated serum urate levels? Rheumatology International 34(6): 743-757.

Gosling, A. L., Matisoo-Smith, E. and Merriman, T. R. 2014b. Gout in Māori. Rheumatology 53(5): 773-774.

Greig, K., Boocock, J., Prost, S., Horsburgh, K. A., Jacomb, C., Walter, R. and Matisoo-Smith, E. 2015. Complete mitochondrial genomes of New Zealand's first dogs. PLoS One 10(10): e0138536.

Gross, B. L. and Zhao, Z. 2014. Archaeological and genetic insights into the origins of domesticated rice. Proceedings of the National Academy of Sciences 111 (17): 6190-6197.

Groube, L. M. 1993. Contradictions and malaria in Melanesian and Australian prehistory. In M. Spriggs, D. Yen, W. Ambrose, R. Jones, A. Thorne and A. Andrews (eds.) A Community of Culture: the People and Prehistory of the Pacific. pp. 164-186. Canberra: ANU Press.

Halcrow, S. E. and Boonlop, K. 2014. Report on the human remains from the Middle Mekong Archaeological Project [Collaborator Report]. In J. C. White (ed.) Strengthening the future of Southeast Asian archaeology: Investigating Prehistoric Settlement of the Middle Mekong Basin [Final Report]. pp. 23-42. Philadelphia, PA: University of Pennsylvania Museum of Archaeology and Anthropology. 
Halcrow, S. E. and Tayles, N. 2011. Human diversity in mainland Southeast Asia: the contribution of bioarchaeology. In N. J. Enfield (ed.) Dynamics of Human Diversity: the Case of Mainland Southeast Asia. pp. 47-61. Canberra: Pacific Linguistics.

Halcrow, S. E., Harris, N., Beavan, N. and Buckley, H. 2014. First bioarchaeological evidence of probable scurvy in Southeast Asia: multifactorial etiologies of vitamin $\mathrm{C}$ deficiency in a tropical environment. International Journal of Paleopathology 5: 63-71.

Halcrow, S. E., Tayles, N. and King, C. L. 2016. Infant and child health and disease with agricultural intensification in mainland Southeast Asia. In M. Oxenham and H. R. Buckley (eds.) The Routledge Handbook of Bioarchaeology in Southeast Asia and the Pacific Islands. pp. 158-186. New York: Routledge.

Hanihara, T. 1992. Dental and cranial affinities among populations of East Asia and the Pacific: The basic populations in East Asia, IV. American Journal of Physical Anthropology 88(2): 163-182.

Hayes, S., Buckley, H., Bradley, R., Milne, N. and Dennison, J. 2012. Approximating the face of 'Aunty': A question of likeness. Journal of Archaeological Method and Theory 19(2): 306-321.

Hellenthal, G., Busby, G. B., Band, G., Wilson, J. F., Capelli, C., Falush, D. and Myers, S. 2014. A genetic atlas of human admixture history. Science 343(6172): 747-751.

Heupink, T. H., Subramanian, S., Wright, J. L., Endicott, P., Westaway, M. C., Huynen, L., Parson, W., Millar, C. D., Willerslev, E. and Lambert, D. M. 2016. Ancient mtDNA sequences from the first Australians revisited. Proceedings of the National Academy of Sciences 113(25): 6892-6897.

Higham, C. F. 2014. From the Iron Age to Angkor: new light on the origins of a state. Antiquity 88(341): 822-835.

Higham, C. F. 2016. At the dawn of history: from Iron Age aggrandisers to Zhenla kings. Journal of Southeast Asian Studies 47(3): 418-437.

Higham, T., Anderson, A. and Jacomb, C. 1999. Dating the first New Zealanders: the chronology of Wairau Bar. Antiquity 73(280): 420-427.

Hill, A., Bowden, D., Trent, R., Higgs, D., Oppenheimer, S., Thein, S., Mickleson, K., Weatherall, D. and Clegg, J. 1985. Melanesians and Polynesians share a unique alphathalassemia mutation. American Journal of Human Genetics 37(3): 571.

Hollis-Moffatt, J. E., Xu, X., Dalbeth, N., Merriman, M. E., Topless, R., Waddell, C., Gow, P. J., Harrison, A. A., Highton, J. and Jones, P. B. 2009. Role of the urate transporter SLC2A9 gene in susceptibility to gout in New Zealand Māori, Pacific Island, and Caucasian case-control sample sets. Arthritis and Rheumatism 60(11): 3485-3492.

Horrocks, M., Neiuwould, M., Kinaston, R., Buckley, H. and Bedford, S. 2014. Microfossil and Fourier Transform InfraRed analyses of Lapita and post-Lapita human dental calculus from Vanuatu, Southwest Pacific. Journal of the Royal Society of New Zealand 44(1): 17-33.

Houghton P. 1975. The people of Wairau Bar. Records of the Canterbury Museum. 9: 231-246.

Huerta-Sanchez, E., Jin, X., Asan, Bianba, Z., Peter, B. M., Vinckenbosch, N., Liang, Y., Yi, X., He, M., Somel, M., Ni, P., Wang, B., Ou, X., Huasang, Luosang, J., Cuo, Z. X. P., Li, K., Gao, G., Yin, Y., Wang, W., Zhang, X., Xu, X.,
Yang, H., Li, Y., Wang, J., Wang, J. and Nielsen, R. 2014. Altitude adaptation in Tibetans caused by introgression of Denisovan-like DNA. Nature 512(7513): 194-197.

Jacomb, C., Holdaway, R. N., Allentoft, M. E., Bunce, M., Oskam, C. L., Walter, R. and Brooks, E. 2014. Highprecision dating and ancient DNA profiling of moa (Aves: Dinornithiformes) eggshell documents a complex feature at Wairau Bar and refines the chronology of New Zealand settlement by Polynesians. Journal of Archaeological Science 50: 24-30

Karlsson, E. K., Kwiatkowski, D. P. and Sabeti, P. C. 2014. Natural selection and infectious disease in human populations. Nature Reviews Genetics 15(6): 379-393.

Kennedy, K. A. 1980. Prehistoric skeletal record of man in South Asia. Annual Review Of Anthropology 9(1): 391-432.

Kinaston, R. L., Anson, D., Petchey, P., Walter, R. and Buckley, H. 2015. Late-Lapita diet and subsistence strategies on Watom Island, Papua New Guinea: new stable isotope evidence from humans and animals. American Journal of Physical Anthropology 157: 30-41.

Kinaston, R. L., Bedford, S., Richards, M., Hawkins, S., Gray, A., Jaouen, K., Valentin, F. and Buckley, H. 2014a. Diet and human mobility from the Lapita to the early Historic Period on Uripiv Island, Northeast Malakula, Vanuatu. PLoS ONE 9(8): e104071.

Kinaston, R. L., Buckley, H. R. and Gray, A. 2013a. Diet and social status on Taumako, a Polynesian outlier in the southeastern Solomon Islands. American Journal of Physical Anthropology 151(4): 589-603.

Kinaston, R. L., Bedford, S., Spriggs, M. and Buckley, H. 2016. Is there a 'Lapita diet'? A comparison of Lapita and postLapita skeletal samples from four Pacific Island archaeological sites. In M. Oxenham and H. Buckley (eds.) The Routledge Handbook of Bioarchaeology in Southeast Asia and the Pacific Islands. pp. 427-461. New York: Routledge.

Kinaston, R. L., Buckley, H., Gray, A., Shaw, B. and Mandui, H. 2013b. Exploring subsistence and cultural complexes on the south coast of Papua New Guinea using palaeodietary analyses. Journal of Archaeological Science 40(2): 904913.

Kinaston, R. L., Buckley, H. R., Halcrow, S. E., Spriggs, M. J., Bedford, S., Neal, K. and Gray, A. 2009. Investigating foetal and perinatal mortality in prehistoric skeletal samples: a case study from a 3000-year-old Pacific Island cemetery site. Journal of Archaeological Science 36(12): 2780-2787.

Kinaston, R. L., Buckley, H. R., Valentin, F., Bedford, S., Spriggs, M., Hawkins, S. and Herrscher, E. 2014b. Lapita diet, subsistence strategies and methods of animal husbandry in Remote Oceania: new stable isotope evidence from the 300-year-old Teouma site, Efate Island, Vanuatu. PLoS ONE 9(3): e90376.

Kinaston, R. L., Walter, R. K., Jacomb, C., Brooks, E., Tayles, N., Halcrow, S. E., Stirling, C., Reid, M., Gray, A. R. and Spinks, J. 2013c. The first New Zealanders: patterns of diet and mobility revealed through isotope analysis. PLoS One 8(5): e64580.

King, C. L., Halcrow, S., Tayles, N. and Shkrum, S. A. 2017. Considering the palaeoepidemiological implications of socioeconomic and environmental change in Southeast Asia. Archaeological Research in Asia (Early view). 
Kirch, P. V. 1988. Long-distance exchange and island colonization: the Lapita case. Norwegian Archaeological Review 21(2): 103-117.

Kirch, P. V. 2000. On the Road of the Winds: An Archaeological History of the Pacific Islands before European Contact, Berkley, CA: University of California Press.

Kirch, P. V. 2010. Peopling of the Pacific: a holistic anthropological perspective. Annual Review of Anthropology 39: 131-148.

Kirch, P. V., Swindler, D. R. and Turner, C. G. 1989. Human skeletal and dental remains from Lapita sites (1600-500 B.C. ) in the Mussau Islands, Melanesia. American Journal of Physical Anthropology 79(1): 63-76.

Knapp, M., Horsburgh, K. A., Prost, S., Stanton, J.-A., Buckley, H. R., Walter, R. K. and Matisoo-Smith, E. A. 2012. Complete mitochondrial DNA genome sequences from the first New Zealanders. Proceedings of the National Academy of Sciences 109(45): 18350-18354.

Koboldt, D. C., Steinberg, K. M., Larson, D. E., Wilson, R. K. and Mardis, E. R. 2013. The next-generation sequencing revolution and its impact on genomics. Cell 155(1): 27-38.

Kwiatkowski, D. P. 2005. How malaria has affected the human genome and what human genetics can teach us about malaria. The American Journal of Human Genetics 77(2): 171-192.

Lape, P. V. 2004. The isolation metaphor in island archaeology. In S. M. Fitzpatrick (ed.) Voyages of Discovery: The Archaeology of Islands. pp. 223-232. London: Praeger.

Larsen, C. S. 1995. Biological changes in human populations with agriculture. Annual Review of Anthropology 24: 185-213.

Larsen, C. S. 2015. Bioarchaeology: Interpreting Behavior from the Human Skeleton, Cambridge: Cambridge University Press.

Larsen, C. S. and Walker, P. L. 2005. The ethics of bioarchaeology. In T. Turner (ed.) Biological Anthropology and Ethics: From Repatriation to Genetic Identity. pp. 111-119. New York: State University of New York Press.

Larson, G., Cucchi, T., Fujita, M., Matisoo-Smith, E., Robins, J., Anderson, A., Rolett, B., Spriggs, M., Dolman, G. and Kim, T.-H. 2007. Phylogeny and ancient DNA of Sus provides insights into Neolithic expansion in Island Southeast Asia and Oceania. Proceedings of the National Academy of Sciences 104(12): 4834-4839.

Lilley, I. 2017. The Indo-Pacific Prehistory Association [Online]. Available: http://ippa.anu.edu.au/ [Accessed 01/08/17].

Linderholm, A. 2016. Ancient DNA: the next generation-chapter and verse. Biological Journal of the Linnean Society 117(1): $150-160$.

Lipson, M., Loh, P.-R., Patterson, N., Moorjani, P., Ko, Y.-C., Stoneking, M., Berger, B. and Reich, D. 2014. Reconstructing Austronesian population history in Island Southeast Asia. Nature Communications 5: 1-7.

Lovell, N.C. and Kennedy, K.A. 1989. Society and disease in prehistoric South Asia. In J. Kenoyer (ed. ), Old Problems and New Perspectives in the Archaeology of South Asia, pp. 89-92. Madison, WI: University of Wisconsin.

Malaspinas, A.-S., Westaway, M. C., Muller, C., Sousa, V. C., Lao, O., Alves, I., Bergström, A., Athanasiadis, G., Cheng, J. Y., Crawford, J. E., Heupink, T., Macholdt, E., Peischl, S., Rasmussen, S., Schiffels, S., Subramanian, S., Wright,
J., Albrechtsen, A., Barbieri, C., Dupanloup, I., Eriksson, A., Margaryan, A., Moltke, I., Pugach, I., Korneliussen, T., Levkivskyi, I., Moreno-Mayar, J., Ni, S., Racimo, F., Sikora, M., Xue, Y., Aghakhanian, F., Brucato, N., Brunak, S., Campos, P., Clark, W., Ellingvåg, S., Fourmile, G., Gerbault, P., Injie, D., Koki, G., Leavesley, M., Logan, B., Lynch, A., Matisoo-Smith, E., Mcallister, P., Mentzer, A., Metspalu, M., Migliano, A., Murgha, L., Phipps, M., Pomat, W., Reynolds, D., Ricaut, F.-X., Siba, P., Thomas, M., Wales, T., Wall, C., Oppenheimer, S., Tyler-Smith, C., Durbin, R., Dortch, J., Manica, A., Schierup, M., Foley, R., Lahr, M., Bowern, C., Wall, J., Mailund, T., Stoneking, M., Nielsen, R., Sandhu, M., Excoffier, L., Lambert, D. and Willerslev, E. 2016. A genomic history of Aboriginal Australia. Nature 538: 207-214.

Mallick, S., Li, H., Lipson, M., Mathieson, I., Gymrek, M., Racimo, F., Zhao, M., Chennagiri, N., Nordenfelt, S., Tandon, A., Skoglund, P., Lazaridis, I., Sankararaman, S., Fu, Q., Rohland, N., Renaud, G., Erlich, Y., Willems, T., Gallo, C., Spence, J. P., Song, Y. S., Poletti, G., Balloux, F., van Driem, G., de Knijff, P., Romero, I. G., Jha, A. R., Behar, D. M., Bravi, C. M., Capelli, C., Hervig, T., Moreno-Estrada, A., Posukh, O. L., Balanovska, E., Balanovsky, O., Karachanak-Yankova, S., Sahakyan, H., Toncheva, D., Yepiskoposyan, L., Tyler-Smith, C., Xue, Y., Abdullah, M. S., Ruiz-Linares, A., Beall, C. M., Di Rienzo, A., Jeong, C., Starikovskaya, E. B., Metspalu, E., Parik, J., Villems, R., Henn, B. M., Hodoglugil, U., Mahley, R., Sajantila, A., Stamatoyannopoulos, G., Wee, J. T. S., Khusainova, R., Khusnutdinova, E., Litvinov, S., Ayodo, G., Comas, D., Hammer, M. F., Kivisild, T., Klitz, W., Winkler, C. A., Labuda, D., Bamshad, M., Jorde, L. B., Tishkoff, S. A., Watkins, W. S., Metspalu, M., Dryomov, S., Sukernik, R., Singh, L., Thangaraj, K., Pääbo, S., Kelso, J., Patterson, N. and Reich, D. 2016. The Simons Genome Diversity Project: 300 genomes from 142 diverse populations. Nature 538(7624): 201-206.

Marwick, B. 2009. Biogeography of middle Pleistocene hominins in mainland Southeast Asia: a review of current evidence. Quaternary International 202(1): 51-58.

Matisoo-Smith, E. 2015. Ancient DNA and the human settlement of the Pacific: A review. Journal of Human Evolution 79: 93-104.

Matisoo-Smith, E. 2016. Human biology and population histories in the Pacific-is there such thing as a Lapita people? In M. Oxenham and H. Buckley (eds.) The Routledge Handbook of Bioarchaeology in Southeast Asia and the Pacific Islands. pp. 389-408. New York: Routledge.

Matisoo-Smith, E. and Daugherty, C. 2012. Africa to Aotearoa: the longest migration. Journal of the Royal Society of New Zealand 42(2): 87-92.

Matisoo-Smith, E., Hingston, M., Summerhayes, G., Robins, J., Ross, H. and Hendy, M. 2009. On the rat trail in Near Oceania: applying the commensal model to the question of the Lapita colonization. Pacific Science 63(4): 465-475.

Matsumura, H. and Hudson, M. J. 2005. Dental perspectives on the population history of Southeast Asia. American Journal of Physical Anthropology 127: 182-209.

Matsumura, H. and Oxenham, M. F. 2014. Demographic transitions and migration in prehistoric East/Southeast Asia through the lens of nonmetric dental traits. American Journal of Physical Anthropology 155(1): 45-65. 
Matsumura, H., Oxenham, M. F., Dodo, Y., Domett, K., Thuy, N. K., Cuong, N. L., Dung, N. K., Huffer, D. and Yamagata, M. 2008a. Morphometric affinity of the late Neolithic human remains from Man Bac, Ninh Binh Province, Vietnam: key skeletons with which to debate the 'two layer'hypothesis. Anthropological Science (116): 135-148.

Matsumura, H., Oxenham, M., Thuy, N., Cuong, N. and Dung, N. 2011. The population history of mainland Southeast Asia: two layer model in the context of northern Vietnam. In N. Enfield (ed.) Dynamics of Human Diversity: the Case of Mainland Southeast Asia. pp. 153-178. Canberra: Pacific Linguistics.

Matsumura, H., Yoneda, M., Dodo, Y., Oxenham, M. F., Cuong, N. L., Thuy, N. K., Dung, L. M., Long, V. T., Yamagata, M. and Sawada, J. 2008b. Terminal Pleistocene human skeleton from Hang Cho Cave, northern Vietnam: implications for the biological affinities of Hoabinhian people. Anthropological Science 116(3): 201-217.

McNiven, I. J., David, B., Richards, T., Aplin, K., Asmussen, B., Mialanes, J., Leavesley, M., Faulkner, P. and Ulm, S. 2011. New directions in human colonisation of the Pacific: Lapita settlement of south coast New Guinea. Australian Archaeology (72): 1-6.

Mokrousov, I., Vyazovaya, A., Iwamoto, T., Skiba, Y., Pole, I., Zhdanova, S., Arikawa, K., Sinkov, V., Umpeleva, T. and Valcheva, V. 2016. Latin-American-Mediterranean lineage of Mycobacterium tuberculosis: human traces across pathogen's phylogeography. Molecular Phylogenetics and Evolution 99: 133-143.

Mushrif-Tripathy, V., Chakraborty, K.S. and Lahiri, S. 2016. Where are they now? The human skeletal remains from India. In G.R. Schug and S. Walimbe (eds.) A Companion to South Asia in the Past. pp. 496- 533. Hoboken, NJ: John Wiley and Sons Inc.

O'Reilly, D. 2014. Increasing complexity and the political economy model; a consideration of Iron Age moated sites in Thailand. Journal of Anthropological Archaeology 35: 297-309.

Oskarsson, M. C., Klütsch, C. F., Boonyaprakob, U., Wilton, A., Tanabe, Y. and Savolainen, P. 2011. Mitochondrial DNA data indicate an introduction through mainland Southeast Asia for Australian dingoes and Polynesian domestic dogs. Proceedings of the Royal Society of London B: Biological Sciences 279: 967-974.

Oxenham, M. F., Thuy, N. K. and Cuong, N. L. 2005. Skeletal evidence for the emergence of infectious disease in Bronze and Iron Age northern Vietnam. American Journal of Physical Anthropology 126(4): 359-376.

Pagani, L., Lawson, D. J., Jagoda, E., Mörseburg, A., Eriksson, A., Mitt, M., Clemente, F., Hudjashov, G., DeGiorgio, M., Saag, L., Wall, J., Cardona, A., Mägi, R., Sayres, M., Kaewert, S., Inchley, C., Scheib, C., Järve, M., Karmin, M., Jacobs, G., Antao, T., Iliescu, F., Kushniarevich, A., Ayub, Q., Tyler-Smith, C., Xue, Y., Yunusbayev, B., Tambets, K., Mallick, C., Saag, L., Pocheshkhova, E., Andriadze, G., Muller, C., Westaway, M., Lambert, D., Zoraqi, G., Turdikulova, S., Dalimova, D., Sabitov, Z., Sultana, G., Lachance, J., Tishkoff, S., Momynaliev, K., Isakova, J., Damba, L., Gubina, M., Nymadawa, P., Evseeva, I., Atramentova, L., Utevska, O., Ricaut, F.-X., Brucato, N., Sudoyo, H., Letellier, T., Cox, M. P., Barashkov, N., Škaro, V., Mulahasanovic', L., Primorac, D., Sahakyan, H., Mormina, M., Eichstaedt, C., Lichman, D., Abdullah, S.,
Chaubey, G., Wee, J., Mihailov, E., Karunas, A., Litvinov, S., Khusainova, R., Ekomasova, N., Akhmetova, V., Khidiyatova, I., Marjanović, D., Yepiskoposyan, L., Behar, D., Balanovska, E., Metspalu, A., Derenko, M., Malyarchuk, B., Voevoda, M., Fedorova, S., Osipova, L., Lahr, M., Gerbault, P., Leavesley, M., Migliano, A., Petraglia, M., Balanovsky, O., Khusnutdinova, E., Metspalu, E., Thomas, M., Manica, A., Nielsen, R., Villems, R., Willerslev, E., Kivisild, T. and Metspalu, M. 2016. Genomic analyses inform on migration events during the peopling of Eurasia. Nature 538(7624): 238-242.

Pang, J.-F., Kluetsch, C., Zou, X. J., Zhang, A. B., Luo, L. Y., Angleby, H., Ardalan, A., Ekström, C., Sköllermo, A. and Lundeberg, J. 2009. mtDNA data indicate a single origin for dogs south of Yangtze River, less than 16,300 years ago, from numerous wolves. Molecular Biology and Evolution 26(12): 2849-2864.

Parks, M., Subramanian, S., Baroni, C., Salvatore, M., Zhang, G., Millar, C. and Lambert, D. 2015. Ancient population genomics and the study of evolution. Philosophical Transactions of the Royal Society of London B: Biological Sciences 370(1660): 20130381

Perrier, X., Langhe, E. D., Donohue, M., Lentfer, C., Vrydaghs, L., Bakry, F., Carreel, F., Hippolyte, I., Horry, J. P., Jenny, C., Lebot, V., Risterucci, A. M., Tomekpe, K., Doutrelepont, H., Ball, T., Manwaring, J., Maret, P. D. and Denham, T. 2011. Multidisciplinary perspectives on banana (Musa spp.) domestication. Proceedings of the National Academy of Sciences 108(28): 11311-11318.

Peterson, W. 1982. Colonialism, culture history, and Southeast Asian prehistory. Asian Perspectives 25(1): 123-132.

Philippon, G., Martinson, J., Rugless, M., Moulia-Pelat, J., Plichart, R., Roux, J. F., Martin, P. and Clegg, J. 1995. $\alpha$ Thalassaemia and globin gene rearrangements in French Polynesia. European Journal of Haematology 55(3): 171177.

Phipps-Green, A. J., Hollis-Moffatt, J. E., Dalbeth, N., Merriman, M. E., Topless, R., Gow, P. J., Harrison, A. A., Highton, J., Jones, P. B. and Stamp, L. K. 2010. A strong role for the ABCG2 gene in susceptibility to gout in New Zealand Pacific Island and Caucasian, but not Māori, case and control sample sets. Human Molecular Genetics 19: 48319.

Pietrusewsky, M. 1996a. The physical anthropology of Polynesia: a review of some cranial and skeletal studies. In J. M. Davidson, G. Irwin, B. Leach, A. Pawley and D. Brown (eds.) Oceanic Culture History: Essays in Honour of Roger Green. pp. 343-353. Wellington: New Zealand Journal of Archaeology Special Publications.

Pietrusewsky, M. 1996b. Multivariate craniometric investigations of Japanese, Asians, and Pacific islanders. In K. Omoto (ed.) Interdisciplinary Perspectives on the Origins of the Japanese, International Symposium. pp. 65-104. Kyoto: International Centre for Japanese Studies.

Pietrusewsky, M. and Douglas, M. T. 2001. Intensification of agriculture at Ban Chiang: is there evidence from the skeletons? Asian Perspectives 40(2): 157-178.

Pietrusewsky, M. and Douglas, M. T. 2002. Ban Chiang, A prehistoric village site in Northeast Thailand I: the Human Skeletal Remains, Philadelphia, University of Pennsylvania Museum of Archaeology and Anthropology. 
Pietrusewsky M., Douglas, M. T., and Ikehara-Quebral, R. M. 1997. An assessment of health and disease in the prehistoric inhabitants of the Mariana Islands. American Journal of Physical Anthropology. 104: 315-42.

Pietrusewsky M., Douglas, M. T., Swift, M. K., Harper, R. A., Fleming, M. A. 2014. Health in Ancient Mariana Islanders: A Bioarchaeological Perspective. The Journal of Island and Coastal Archaeology. 9: 319-40.

Pinhasi, R. and Stock, J. T. (eds.) 2011. Human Bioarchaeology of the Transition to Agriculture. Chichester, UK: John Wiley and Sons.

Pitt, J., Gillingham, P. K., Maltby, M. and Stewart, J. R. 2016. New perspectives on the ecology of early domestic fowl: An interdisciplinary approach. Journal of Archaeological Science 74: 1-10.

Rasmussen, M., Guo, X., Wang, Y., Lohmueller, K. E., Rasmussen, S., Albrechtsen, A., Skotte, L., Lindgreen, S., Metspalu, M. and Jombart, T. 2011. An Aboriginal Australian genome reveals separate human dispersals into Asia. Science 334(6052): 94-98.

Reich, D., Green, R. E., Kircher, M., Krause, J., Patterson, N., Durand, E. Y., Viola, B., Briggs, A. W., Stenzel, U. and Johnson, P. L. 2010. Genetic history of an archaic hominin group from Denisova Cave in Siberia. Nature 468(7327): 1053-1060.

Roberts, C. A. and Cox, M. 2003. Health and Disease in Britain : From Prehistory to the Present day. Stroud, UK: Sutton.

Roullier, C., Benoit, L., McKey, D. B. and Lebot, V. 2013. Historical collections reveal patterns of diffusion of sweet potato in Oceania obscured by modern plant movements and recombination. Proceedings of the National Academy of Sciences 110(6): 2205-2210.

Ruckstuhl, K., Tayles, N., Buckley, H., Bradley, R., Fyfe, R. and Ellison, M. 2016. The ancestors speak: kōiwi tangata, mātauranga Māori and the development of biological anthropology in New Zealand. In M. Oxenham and H. Buckley (eds.) The Routledge Handbook of bioarchaeology in Southeast Asia and the Pacific Islands. pp. 637-654. New York: Routledge.

Sankararaman, S., Mallick, S., Patterson, N. and Reich, D. 2016. The combined landscape of Denisovan and Neanderthal ancestry in present-day humans. Current Biology 26(9): 1241-1247.

Shaw, B., Buckley, H., Summerhayes, G., Anson, D., Garling, S., Valentin, F., Mandui, H., Stirling, C. and Reid, M. 2010. Migration and mobility at the Late Lapita site of ReberRakival (SAC), Watom Island using isotope and trace element analysis: a new insight into Lapita interaction in the Bismarck Archipelago. Journal of Archaeological Science 37(3): 605-613.

Shaw, B., Buckley, H., Summerhayes, G., Stirling, C. and Reid, M. 2011. Prehistoric migration at Nebira, South Coast of Papua New Guinea: new insights into interaction using isotope and trace element concentration analyses. Journal of Anthropological Archaeology 30(3): 344-358.

Shaw, B., Summerhayes, G. R., Buckley, H. R. and Baker, J. A. 2009. The use of strontium isotopes as an indicator of migration in human and pig Lapita populations in the Bismarck Archipelago, Papua New Guinea. Journal of Archaeological Science 36(4): 1079-1091.

Sithithaworn, P. and Haswell-Elkins, M. 2003. Epidemiology of Opisthorchis viverrini. Acta Tropica 88(3): 187-194.
Skoglund, P., Posth, C., Sirak, K., Spriggs, M., Valentin, F., Bedford, S., Clark, G. R., Reepmeyer, C., Petchey, F. and Fernandes, D. 2016. Genomic insights into the peopling of the southwest Pacific. Nature 538: 510-513.

Snow, C. E. 1974. Early Hawaiians: An Initial Study of Skeletal Remains from Mokapu, Oahu, Lexington: University Press of Kentucky.

Spriggs, M. 1997. The Island Melanesians, Cambridge, MA: Blackwell Publishers.

Spriggs, M. 2011. Archaeology and the Austronesian expansion: where are we now? Antiquity 85(328): 510-528.

Spriggs, M. 2016. What archaeologists want human biologists to tell them, about Teouma for example. In M. Oxenham and H. Buckley (eds.) The Routledge Handbook of Bioarchaeology in Southeast Asia and the Pacific Islands. pp. 623-636. New York: Routledge.

Stantis, C., Kinaston, R. L., Richards, M. P., Davidson, J. M. and Buckley, H. R. 2015. Assessing human diet and movement in the Tongan maritime chiefdom using isotopic analyses. PLoS One 10(3): e0123156.

Stantis, C., Buckley, H. R., Kinaston, R. L., Nunn, P. D., Jaouen, K., \& Richards, M. P. 2016a. Isotopic evidence of human mobility and diet in a prehistoric/protohistoric Fijian coastal environment (c. 750-150 BP). American Journal of Physical Anthropology, 159(3), 478-495.

Stantis, C., Tayles, N., Kinaston, R. L., Cameron, C., Nunn, P., Richards, M. P. and Buckley, H. R. 2016b. Diet and subsistence in Remote Oceania: an analysis using oral indicators of diet. In M. Oxenham and H. Buckley (eds.) The Routledge Handbook of Bioarchaeology in Southeast Asia and the Pacific Islands. pp. 569-598. New York: Routledge.

Steckel, R. H. and Rose, J. C. 2002. The Backbone of History : Health and Nutrition in the Western Hemisphere. Cambridge: Cambridge University Press.

Stefan, V. H. and Gill, G. W. 2016. Skeletal Biology of the Ancient Rapanui (Easter Islanders), Cambridge: Cambridge University Press.

Storey, A. A., Quiroz, D., Beavan, N. and Matisoo-Smith, E. 2013. Polynesian chickens in the New World: a detailed application of a commensal approach. Archaeology in Oceania 48(2): 101-119.

Stringer, C. 2014. Human evolution: small remains still pose big problems. Nature 514(7523): 427-429.

Summerhayes, G. R., Leavesley, M., Fairbairn, A., Mandui, H., Field, J., Ford, A. and Fullagar, R. 2010. Human adaptation and plant use in highland New Guinea 49,000 to 44,000 years ago. Science 330(6000): 78-81.

Tayles, N. 1999. The Excavation of Khok Phanom Di, a Prehistoric site in Central Thailand. Vol. V: the People London: Society of Antiquaries of London.

Tayles, N. and Buckley, H. R. 2004. Leprosy and tuberculosis in Iron Age southeast Asia? American Journal of Physical Anthropology 125(3): 239-256.

Tayles, N., Domett, K. and Halcrow, S. 2009. Can dental caries be interpreted as evidence of farming? The Asian experience. In T. Koppe, G. Mayer and K. Alt (eds.) Comparative Dental Morphology. pp. 162-166. Basel: Karger. 
Tayles, N., Domett, K. and Nelsen, K. 2000. Agriculture and dental caries? The case of rice in prehistoric Southeast Asia. World Archaeology 32(1): 68-83.

Temple, D. H. and Goodman, A. H. 2014. Bioarcheology has a "health" problem: conceptualizing "stress" and "health" in bioarcheological research. American Journal of Physical Anthropology, 155(2): 186-191.

Thorne, A. G. 1980. The longest link: human evolution in southeast Asia and the settlement of Australia. In J. Fox (ed.) Indonesia: Australian Perspectives. pp. 35-43. Canberra: ANU Press.

Trembly, D. L. 1996. Treponematosis in pre-Spanish western Micronesia. International Journal of Osteoarchaeology 6(4): 397-402.

Tromp, M. 2016. Lapita plants, people and pigs [unpublished $\mathrm{PhD}$ thesis]. Department of Anatomy, University of Otago.

Tromp, M. and Dudgeon, J. V. 2015. Differentiating dietary and non-dietary microfossils extracted from human dental calculus: the importance of sweet potato to ancient diet on Rapa Nui. Journal of Archaeological Science 54: 54-63.

Ubalee, R., Tsukahara, T., Kikuchi, M., Lum, J. K., Dzodzomenyo, M., Kaneko, A. and Hirayama, K. 2005. Associations between frequencies of a susceptible TNF- $\alpha$ promoter allele and protective $\alpha$-thalassaemias and malaria parasite incidence in Vanuatu. Tropical Medicine and International Health 10(6): 544-549.

Valentin, F., Bocherens, H., Gratuze, B. and Sand, C. 2006. Dietary patterns during the late prehistoric/historic period in Cikobia island (Fiji): insights from stable isotopes and dental pathologies. Journal of Archaeological Science 33(10): 1396-1410.

Valentin, F., Buckley, H., Herrscher, E., Kinaston, R., Bedford, S., Spriggs, M., S, H. and Neal, K. 2010. Lapita subsistence strategies and food consumption patterns in the community of Teouma (Efate, Vanuatu). Journal of Archaeological Science 37: 1820-1829.

Valentin, F., Détroit, F., Spriggs, M. J. and Bedford, S. 2016. Early Lapita skeletons from Vanuatu show Polynesian craniofacial shape: implications for Remote Oceanic settlement and Lapita origins. Proceedings of the National Academy of Sciences 113(2): 292-297.

Valentin, F., Herrscher, E., Bedford, S., Spriggs, M. and Buckley, H. 2014. Evidence for social and cultural change in central Vanuatu between 3000 and 2000 BP: comparing funerary and dietary patterns of the first and later generations at Teouma, Efate. The Journal of Island and Coastal Archaeology 9(3): 381-399.

Vernot, B., Tucci, S., Kelso, J., Schraiber, J. G., Wolf, A. B., Gittelman, R. M., Dannemann, M., Grote, S., McCoy, R. C. and Norton, H. 2016. Excavating Neandertal and Denisovan DNA from the genomes of Melanesian individuals. Science 352(6282): 235-239.

Wall, J. D., Yang, M. A., Jay, F., Kim, S. K., Durand, E. Y., Stevison, L. S., Gignoux, C., Woerner, A., Hammer, M. F. and Slatkin, M. 2013. Higher levels of Neanderthal ancestry in East Asians than in Europeans. Genetics 194(1): 199-209.

Walter, R., Smith, I. and Jacomb, C. 2006. Sedentism, subsistence and socio-political organization in prehistoric New Zealand. World Archaeology 38(2): 274-290.

Wang, G.-D., Zhai, W., Yang, H.-C., Wang, L., Zhong, L., Liu, Y.-H., Fan, R.-X., Yin, T.-T., Zhu, C.-L., Poyarkov, A. D.,
Irwin, D. M., Hytonen, M. K., Lohi, H., Wu, C.-I., Savolainen, P. and Zhang, Y.-P. 2015. Out of southern East Asia: the natural history of domestic dogs across the world. Cell Research 26(1): 21-33.

Ward, S. M., Halcrow, S. E., Buckley, H. R., Higham, C. F. W., O'Reilly, D. J. W., Shewan, L. and Domett, K. M. In Press. The impact of social change on health at the late Iron Age site of Non Ban Jak in northeast Thailand. In N.H. Tan (ed. ) Advancing Southeast Asian Archaeology 2016 - Selected Papers from the 2nd SEAMEO SPAFA International Conference on Southeast Asian Archaeology, Bangkok 2016. Bangkok: SEAMEO SPAFA Regional Centre for Archaeology and Fine Arts

Watkins, J. 2003. Archaeological Ethics and American Indians. In L. Zimmerman, K. Vitelli and J. Hollowell-Zimmer (eds.) Ethical Issues in Archaeology. pp. 129-141. New York: Altamira Press.

Weisler, M. I., Bolhar, R., Ma, J., St Pierre, E., Sheppard, P., Walter, R. K., Feng, Y., Zhao, J.-x. and Kirch, P. V. 2016. Cook Island artifact geochemistry demonstrates spatial and temporal extent of pre-European interarchipelago voyaging in East Polynesia. Proceedings of the National Academy of Sciences 113(29): 8150-8155.

Whyte, A.L., Marshall, S.J. and Chambers, G.K., 2005. Human evolution in Polynesia. Human Biology, 77(2): 157-177.

Willis, A. and Oxenham, M. 2013. The Neolithic demographic transition and oral health: the Southeast Asian experience. American Journal of Physical Anthropology 152(2): 197208.

Wilmshurst, J. M., Anderson, A. J., Higham, T. F. and Worthy, T. H. 2008. Dating the late prehistoric dispersal of Polynesians to New Zealand using the commensal Pacific rat. Proceedings of the National Academy of Sciences 105(22): 7676-7680.

Winnard, D., Kake, T., Gow, P., Barratt-Boyes, C., Harris, V., Hall, D.-A., Mason, H., Merriman, T. and Dalbeth, N. 2008. Debunking the myths to provide $21^{\text {st }}$ century management of gout. The New Zealand Medical Journal 121(1274): 79-85.

Wohlfarth, B., Higham, C. F. W., Yamoah, K. A., Chabangborn, A., Chawchai, S. and Smittenberg, R. H. 2016. Human adaptation to mid-to late-Holcone climate change in northeast Thailand. The Holocene 26(11): 1875-1886.

World Health Organisation. 2014. Addressing Diseases of Poverty: an Initiative to Reduce the Unacceptable Burden of Neglected Tropical Diseases in the Asia Pacific Region Manilla: WHO Regional Office for the Western Pacific

Xu, S., Pugach, I., Stoneking, M., Kayser, M., Jin, L. and Consortium, H. P.-A. S. 2012. Genetic dating indicates that the Asian-Papuan admixture through eastern Indonesia corresponds to the Austronesian expansion. Proceedings of the National Academy of Sciences 109(12): 4574-4579.

Yamoah, K. A., Higham, C. F., Wohlfarth, B., Chabangborn, A., Chawchai, S., Schenk, F. and Smittenberg, R. H. 2017. Societal response to monsoonal fluctuations in NE Thailand during the demise of Angkor Civilisation. The Holocene (Early View).

Yen, D. E. 1991. Polynesian cultigens and cultivars: the question of origin. In D. A. Cox and S. A. Banack (eds.) Islands, Plants and Polynesians: an Introduction to Polynesian Ethnobotany. pp. 67-95. Portland, OR: Dioscorides Press. 